\title{
Variable expression of immunoreactive surface proteins of Propionibacterium acnes
}

\section{Correspondence \\ Sheila Patrick \\ s.patrick@qub.ac.uk}

Received 14 June 2006

Revised 25 July 2006

Accepted 21 August 2006
Michael J. Lodes, ${ }^{1} \dagger \ddagger$ Heather Secrist, ${ }^{1} \dagger$ Darin R. Benson, ${ }^{1} \dagger$ Shyian Jen, ${ }^{1}$ Kurt D. Shanebeck, ${ }^{1}$ Jeffrey Guderian, ${ }^{1}$ Jean-François Maisonneuve, ${ }^{1}$ Ajay Bhatia, ${ }^{1}$ David Persing, ${ }^{1} \S$ Sheila Patrick ${ }^{2}$ and Yasir A. W. Skeiky ${ }^{1} \|$

${ }^{1}$ Corixa Corporation, Infectious Disease Research Institute, Seattle, WA 98101, USA

${ }^{2}$ Microbiology Building, School of Medicine and Dentistry, Queen's University Belfast, Grosvenor Road, Belfast BT12 6BN, UK

Despite accumulating data implicating Propionibacterium acnes in a variety of diseases, its precise role in infection remains to be determined. $P$. acnes antigen-specific CD4 ${ }^{+} \mathrm{T}$ cells are present in early inflamed acne lesions and may be involved in the inflammatory response; however, little is known about the specific antigens involved. In this study, B cell and T cell antigens from $P$. acnes expression libraries were cloned and evaluated and the four predominant proteins identified were investigated. Two of these antigens share some homology with an M-like protein of Streptococcus equi and have dermatan-sulphate-binding activity (PA-25957 and 5541). The remaining two antigens, PA-21693 and 4687, are similar to the product of the Corynebacterium diphtheriae htaA gene from the $h m u$ ABC transport locus, although only one of these (PA-21693) is encoded within an $h m u$-like operon and conserved amongst a range of clinical isolates. All four proteins contain an LPXTG motif, although only PA-21693 contains a characteristic sortase-sorting signal. Variation in the expression of PA-4687, 25957 and 5541 is evident amongst clinical isolates and is generated both by frameshifts associated with the putative signal peptide and by variable numbers of repeat regions toward the carboxy-terminus, potentially generating heterogeneity of molecular mass and antigenic variation. In addition, in the case of PA-25957, a frameshift in a C-rich region at the extreme carboxy-terminus eliminates the LPXTG motif in some isolates. For the dermatan-sulphate-binding PA-25957, IgG1 antibody in serum from acne-positive donors was shown to be specific for the amino-terminal region of the protein, which also contains a CD4 ${ }^{+}$ T cell epitope. In contrast, serum from acne-negative donors shows an IgG2 and IgG3 antibody subclass response to the carboxy-terminal region. These data have implications for the potential role of $P$. acnes in inflammatory acne and other diseases.

\section{INTRODUCTION}

Propionibacterium acnes, formerly assigned to the genus Corynebacterium (e.g. Corynebacterium parvum; Johnson \& Cummins, 1972) is a Gram-positive bacterium that is commonly found on the skin but may also inhabit the conjunctiva, respiratory tract, genitourinary tract and

†These authors contributed equally to this work.

łPresent address: CombiMatrix Corporation, Mukilteo, WA 98275, USA.

§Present address: Cepheid, Sunnyvale, CA 94089, USA.

||Present address: Aeras Global TB Vaccine Foundation, Bethesda, MD 20814, USA.

Abbreviations: HRP, horseradish peroxidase; PBMCs, peripheral blood mononuclear cells; RCF, relative centrifugal force.

There are two supplementary sequence alignments with the online version of this paper. gastrointestinal tract of humans (Ingham, 1999). Although $P$. acnes may be aerotolerant (Cove et al., 1983) it is treated as an anaerobe in the clinical setting (Jousimies-Somer et al., 2002), as anaerobic conditions are necessary for optimal isolation from samples (Tunney et al., 1998). The immunomodulatory properties of $P$. acnes have been exploited in animal models of cancer, infections and inflammatory diseases (e.g. Bojar \& Holland, 2004; Ingham, 1999). In addition it has been used as an anti-tumour agent in humans (Davies, 1982). P. acnes is implicated in inflammatory diseases such as acne vulgaris (Ingham, 1999), sarcoidosis (Moller \& Chen, 2002), keratitis (Wong et al., 2003), synovitis acne pustulosis hyperostosis osteitis (SAPHO) syndrome (Kirchhoff et al., 2003), endocarditis (Brook, 2002), and potentially fatal granuloma after trauma (Gao et al., 2002). It is also frequently present in medical implant biofilm infection (Tunney et al., 1999; Zedtwitz-Liebenstein et al., 2003). Despite this, the pathogenic potential of $P$ acnes 
has been questioned, partly because of the potential for contamination of clinical samples with bacteria of the normal skin microbiota.

Several lines of evidence clearly implicate $P$. acnes as an important component in the development of inflammatory acne. $P$. acnes colonizes sebaceous follicles after sebum production begins and releases lipases, lytic enzymes and proinflammatory substances that are chemotactic for inflammatory cells, can activate mononuclear cells and are mitogenic for T cells (Jappe et al., 2002; Leyden et al., 1998). In addition, although the specific components of $P$. acnes that interact with Toll-like receptors have yet to be identified, an unspecified $P$. acnes isolate induced the release of the inflammatory cytokines IL- 8 and IL-12 in human macrophages via a TLR2-dependent pathway (Kim et al., 2002), and Nagy et al. (2005) presented evidence that both TLR-2 and TLR- 4 are involved in P. acnes-induced secretion of IL- 8 by keratinocytes. $P$. acnes can also promote the synthesis of IL-18, which, in the presence of IL-12, is a pivotal mediator of the Th1 cytokine response (Braga et al., 2003; Matsui et al., 1997). Type 1A and 1B P. acnes have also been shown to induce proinflammatory/chemokine secretion in a sebocyte cell line (Nagy et al., 2006). In addition, antibiotic resistance in $P$. acnes has been associated with therapeutic failure in the treatment of acne vulgaris (Eady et al., 1989) and is increasingly becoming a widespread phenomenon (Eady et al., 2003). Although little is known about $P$. acnes polypeptide antigens that might be involved in the pathogenesis of acne vulgaris, Holland et al. (1993) have shown that patients with acne have a greater antibody response to a selected range of $P$. acnes polypeptides than do control patients; and that acne patients have immunoglobulins to a limited range of $P$. acnes polypeptides that are not recognized in serum from normal controls.

Serological expression screening as a mechanism to obtain antigens with both $\mathrm{B}$ cell and T cell epitopes is supported by studies showing that both antigen-specific Th1 and Th2 cells clonally expand and migrate to B cell follicles, where they support antibody production to a similar degree (Smith et al., 2004). Specifically, in vivo-polarized, IFN- $\gamma$-secreting Th1 cells can migrate into B cell follicles to interact with antigen-specific B cells (Smith et al., 2004). Previously, we have successfully used serological expression screening to identify dominant $\mathrm{B}$ cell and $\mathrm{T}$ cell antigens involved in the pathogenesis of Crohn's disease, an inflammatory disease of the gastrointestinal tract that is thought to result from a deregulated mucosal immune response to the intestinal microbiota (Lodes et al., 2004a; Targan et al., 2005). Similar serological expression screening was used in the present study to clone immunologically reactive $P$. acnes antigens that are both $\mathrm{B}$ cell and $\mathrm{T}$ cell antigens.

Here we describe four immunoreactive $P$. acnes surface proteins. Antigens PA-21693 and 4687 are related to the Corynebacterium diphtheriae htaA gene; and antigens PA-25957 and 5541 have some similarity to streptococcal M-like proteins.

\section{METHODS}

Propionibacterium acnes isolates and culture. $P$. acnes isolates were: (1) ATCC 6919 (NCTC 737), PA-4, -7, -9 and -10 (type IA); PA-1 and -13 (type IB); and PA-2, $-3,-5$ and -6 (type II), isolated from acne patients in the west coast of the United States; (2) Z-3, $-4,-7$ and -8 (type IA) from acne patients in the east coast of the United States; and (3) GN-1, -2, GP-1, -2 (type IA) and GN-3 (type IB) isolated from acne patients in Germany. Cloned bacteria were cultured from single-colony-derived glycerol stocks in either thioglycolate (TG) medium at $37^{\circ} \mathrm{C}$ or brain heart infusion (BHI) broth supplemented with $0.5 \%(\mathrm{w} / \mathrm{v})$ glucose at $37^{\circ} \mathrm{C}$ in an anaerobic chamber (ThermoForma) with an atmosphere of $85 \% \mathrm{~N}_{2}, 5 \% \mathrm{CO}_{2}$ and $10 \% \mathrm{H}_{2}$. For studies on iron regulation of protein synthesis, cells were cultured in a defined synthetic medium (Gribbon et al., 1993), with or without $\mathrm{FeSO}_{4}$. Isolate type was determined by phylogenetic analysis based on CAMP-factor gene sequence data (Valanne et al., 2005) and the sequences of the proteins examined in this study.

Human sera. Serum donors were categorized as having a history of mild or no acne (acne-negative), or moderate to severe acne (acnepositive). Two pools of serum samples were prepared for expression clone screening, one with five sera from acne-positive donors and one with five sera from acne-negative donors. Each of the five sera was randomly chosen from either the acne-negative or the acnepositive group. Patient information was documented at the time of specimen collection. This research was approved by the Corixa Corporation ethics committee, and permission was also granted by all subjects.

Isolation of $\boldsymbol{P}$. acnes genomic DNA. P. acnes type IA ATCC 6919, type IB PA-1 and type II PA-2 were cultured in TG medium at $37^{\circ} \mathrm{C}$. Pelleted bacteria were heat-killed at $80^{\circ} \mathrm{C}$ for $20 \mathrm{~min}$ and then treated with $2 \mathrm{ml}$ lysozyme $\left(20 \mathrm{mg} \mathrm{ml}^{-1}\right.$ in TE buffer) for $1 \mathrm{~h}$ at $37^{\circ} \mathrm{C}$. This solution was rocked at room temperature for $10 \mathrm{~min}$ with $40 \mu \mathrm{l}$ proteinase $\mathrm{K}\left(10 \mathrm{mg} \mathrm{ml}^{-1}\right)$ and $140 \mu \mathrm{l} 20 \%$ SDS (Sigma); incubated for $15 \mathrm{~min}$ at $65^{\circ} \mathrm{C}$; and then $0.4 \mathrm{ml} 5 \mathrm{M} \mathrm{NaCl}$ and $0.32 \mathrm{ml}$ of a $10 \%$ CTAB solution $[1 \mathrm{~g}$ cetyltrimethylammonium bromide (Sigma), $1.4 \mathrm{ml} 5 \mathrm{M} \mathrm{NaCl}, 8.6 \mathrm{ml}$ distilled $\mathrm{H}_{2} \mathrm{O}$ ] was added and incubated at $65^{\circ} \mathrm{C}$ for $10 \mathrm{~min}$. DNA was then extracted twice with phenol, followed by extraction with phenol/chloroform/ isoamyl alcohol (24:24:2, by vol.), and then chloroform. Finally the DNA was precipitated with $0 \cdot 6$ vol. 2-propanol and resuspended in TE buffer.

Amplification and sequencing of $\boldsymbol{P}$. acnes clinical isolates. One millilitre of BHI-cultured, cloned bacteria was washed once with PBS by centrifugation, resuspended in $500 \mu \mathrm{l}$ distilled $\mathrm{H}_{2} \mathrm{O}$ and heated at $100{ }^{\circ} \mathrm{C}$ for $10 \mathrm{~min}$. After centrifugation, supernatants were used as template ( $5 \mu \mathrm{l}$ in $100 \mu \mathrm{l}$ reactions) in standard amplification reactions using the Expand High Fidelity PCR System (Roche Applied Science). Amplification products were cleaned with the Qiagen PCR purification kit and sequenced directly without cloning to avoid random mutations in sequences. Sequencing reactions were performed at Corixa Corporation with automated sequencers (Applied Biosystems) and specific primers. DNA Star software was used for sequence analysis.

$\boldsymbol{P}$. acnes cell fractionation. Exponential-phase cultures of $P$. acnes $(200 \mathrm{ml})$ were harvested and centrifuged at $3000 \mathrm{RCF}$ for $20 \mathrm{~min}$ to pellet the bacteria. The culture supernatant was filtered over a $0.22 \mu \mathrm{m}$ PES bottle filter system (Corning) to remove all traces of bacteria and concentrated using a Centricon Plus- 80 filter device (Millipore) with a $5 \mathrm{kDa}$ cutoff. The culture-secreted proteins were buffer-exchanged in $1 \times \mathrm{PBS}, \mathrm{pH} 7 \cdot 2$, according to the manufacturer's instructions and concentrated to approximately $4 \mathrm{ml}$ final volume. Proteins were filtered through a Millex GP filter and 
concentration determined using a BCA kit (Pierce). Whole-cell bacterial lysates were prepared by washing the pellets in PBS three times to remove all traces of growth medium and culture supernatant proteins and lysed by passing through a French press twice. The lysate was centrifuged to separate the soluble and insoluble fractions. Soluble proteins were filtered $(0 \cdot 2 \mu \mathrm{m})$ and the insoluble cell wall fraction was washed three times with PBS, resuspended directly in SDS loading buffer and boiled.

Genomic expression library construction. Genomic DNA $(20 \mu \mathrm{g})$ from ATCC 6919 and clinical isolates PA-1 and PA-2 was resuspended in $400 \mu \mathrm{l}$ TE buffer and sonicated for $5 \mathrm{~s}$ at $30 \%$ continuous power with a Sonic Dismembrator (Fisher Scientific) to generate fragments of approximately $0 \cdot 5-5 \cdot 0 \mathrm{kbp}$. DNA fragments were blunted with T4 DNA polymerase (Invitrogen) and ligated to EcoRI adaptors (Stratagene) with T4 DNA ligase (Stratagene). Adapted inserts were then phosphorylated with $\mathrm{T} 4$ polynucleotide kinase (Stratagene) and size-selected with a Sephacryl S-400-HR column (Sigma). Approximately $0 \cdot 25 \mu \mathrm{g}$ insert was ligated to $1 \cdot 0 \mu \mathrm{g}$ Lambda ZAP Express, EcoRI/CIAP-treated vector (Stratagene) and the ligation mix was packaged with Gigapack III Gold packaging extract (Stratagene) following the manufacturer's instructions (Lodes et al., 2004b).

Expression screening. Immunoreactive proteins were screened from approximately $6 \times 10^{5}$ p.f.u. of the unamplified expression lambda library. Briefly, twenty $150 \mathrm{~mm}$ Petri dishes were plated with Escherichia coli XL-1 Blue MRF' host cells (Stratagene) and approximately $3 \times 10^{4}$ p.f.u. of the unamplified library and incubated at $42{ }^{\circ} \mathrm{C}$ until plaques formed. Dry nitrocellulose filters (Schleicher and Schuell), pre-wetted with $10 \mathrm{mM}$ IPTG, were placed on the plates, which were then incubated overnight at $37^{\circ} \mathrm{C}$. Filters were removed and washed three times with phosphate-buffered saline (PBS) containing $0 \cdot 1 \%$ Tween 20 (Sigma) (PBST), blocked with $1.0 \%$ BSA (Sigma) in PBST, and washed three times with PBST. Filters were next incubated overnight at $4{ }^{\circ} \mathrm{C}$ with $E$. coli lysate-adsorbed human serum $(1: 200$ dilution for IgG $+\mathrm{A}+\mathrm{M}$ and $1: 25$ for IgA, in PBST), washed three times with PBST, and incubated with a goat antimouse $\operatorname{IgG}+\mathrm{A}+\mathrm{M}(\mathrm{H}$ and $\mathrm{L})$ alkaline-phosphatase-conjugated secondary antibody (Jackson ImmunoResearch; diluted 1:10,000 with PBST) for $1 \mathrm{~h}$. Filters were finally washed three times with PBST and twice with alkaline phosphatase buffer $(\mathrm{pH} 9 \cdot 5)$ and developed with NBT/BCIP (Invitrogen). Reactive plaques were then isolated and a second or third plaque purification was performed. Excision of phagemid followed the Stratagene Lambda ZAP Express protocol, and resulting plasmid DNA was sequenced with an automated sequencer (Applied Biosystems) using M13 forward, reverse and sequence-specific internal DNA sequencing primers. Nucleic acid and predicted protein sequences were searched against the GenBank nucleotide and translated databases. Protein analysis was performed with the PSORT program (National Institute for Basic Biology, Okazaki, Japan), SignalP 3.0 (Bendtsen et al., 2004), and with the IDENTIFY program of EMOTIF (Biochemistry, Stanford University). Sequence alignments were produced with the MegAlign program (Clustal) of DNA Star and ClustalW (EMBL-EBI).

Induction of plasmid clones for $\mathbf{T}$ cell proliferation assays. The plasmid clones resulting from the above serological expression screening were transformed into XL10 Gold Ultracompetent cells (Stratagene) in 96-well format and grown overnight at $37^{\circ} \mathrm{C}$, 250 r.p.m., in $200 \mu \mathrm{l} \mathrm{LB}$ broth containing $100 \mu \mathrm{g}$ carbenicillin $\mathrm{ml}^{-1}$ and $34 \mu \mathrm{g}$ chloramphenicol $\mathrm{ml}^{-1}$ (carb/chlor). Next, $20 \mu \mathrm{l}$ of each overnight culture was added to $80 \mu \mathrm{l} 2 \times$ Yeast-Soy medium (yeast extract, $10 \mathrm{~g}$; soy hydrolysate, $16 \mathrm{~g}$; NaCl, $5 \mathrm{~g}$; in 11 double-distilled $\mathrm{H}_{2} \mathrm{O}, \mathrm{pH} 7 \cdot 5$ ) containing (carb/chlor) per well, and incubated at $37^{\circ} \mathrm{C}, 250$ r.p.m. for $1 \mathrm{~h}$. Then $100 \mu \mathrm{l} 2 \times \mathrm{YS}$ medium, containing (carb/chlor), and $4 \mathrm{mM}$ IPTG was added to each well of the 96-well plates and the plates were incubated at $37^{\circ} \mathrm{C}, 250$ r.p.m. for $2 \mathrm{~h}$. Finally, the plates were centrifuged at $3000 \mathrm{RCF}$ for $20 \mathrm{~min}$ and the supernatants were removed by blotting.

Generation of $\boldsymbol{P}$. acnes-specific $\mathbf{T}$ cell lines from healthy donors. PBMCs from healthy donors with no history of inflammatory acne were collected by apheresis. PBMCs $\left(5 \times 10^{6}\right.$ per well $)$ were cultured in 12-well plates (Corning Costar) in $1.5 \mathrm{ml} \mathrm{RPMI}+10 \%$ human serum and a 1:700 dilution of a $10 \%$ solution of live $P$. acnes. Cells were harvested on day 3 and recultured in IL-2 $\left(0 \cdot 5 \mathrm{ng} \mathrm{ml}^{-1}\right)$. Cultures were fed and split as needed. Cells were harvested on day $10-12$ and recultured in resting medium [RPMI $+10 \%$ human serum + IL2 $\left(0 \cdot 5 \mathrm{ng} \mathrm{ml}^{-1}\right)$, IL-4 $\left(0 \cdot 5 \mathrm{ng} \mathrm{ml}^{-1}\right)$ and IL-7 $\left.\left(10 \mathrm{ng} \mathrm{ml}^{-1}\right)\right]$ for an additional 3 days. Restimulation was accomplished using adherent cells from $2 \times 10^{6} \mathrm{X}$-irradiated (3500R) autologous PBMCs per well with $2 \times 10^{5} \mathrm{~T}$ cells in a 12 -well plate. Cells were recultured in IL-2 on day 3, and in resting medium on day 10-12. Lines were expanded using anti-CD3. T cells $\left(3 \times 10^{6}\right)$ were cultured with heterologous PBMCs $\left(2.5 \times 10^{7}\right)$ in RPMI, $10 \%$ human serum, $30 \mathrm{ng} \mathrm{ml}^{-1}$ anti-CD3, and $2 \mathrm{ng} \mathrm{ml}^{-1}$ IL-2 and IL-4 in a $25 \mathrm{~cm}^{2}$ tissue culture flask. Cells were harvested and put into resting medium on day 10-12. Cells were rested at least 3 days prior to use in bioassay.

Proliferation and IFN- $\gamma$ assays. Approximately $2 \times 10^{5} \mathrm{X}$ irradiated autologous PBMCs per well were seeded in a 96-well flatbottom tissue culture plate, and incubated at $37^{\circ} \mathrm{C}$ for $90 \mathrm{~min}$. Plates were washed to remove non-adherent cells, and $50 \mu \mathrm{l}$ antibiotic-free RPMI $+10 \%$ human serum was added to each well. Recombinant proteins were added in $50 \mu \mathrm{l}$ medium. Bacterial pellets containing the serological clones were resuspended in $200 \mu \mathrm{l}$ antibiotic-free medium, and $10 \mu \mathrm{l}$ was added in duplicate to the wells containing the adherent PBMCs. Wells containing bacteria were incubated at $37^{\circ} \mathrm{C}$ for $90 \mathrm{~min}$, and then washed to remove excess bacteria. Each well then received $25000 \mathrm{~T}$ cells in antibioticcontaining medium $[\mathrm{RPMI}+10 \%$ human serum $+50 \mu \mathrm{g}$ gentamicin (Invitrogen) $\mathrm{ml}^{-1}$ ]. Cultures were incubated for 2 days at $37^{\circ} \mathrm{C}$, after which $50 \mu \mathrm{l}$ culture supernatant was removed for assessment of IFN $-\gamma$ by ELISA, and the plates were pulsed with tritiated thymidine $\left(1 \mu \mathrm{Ci} \mathrm{ml}{ }^{-1}, 37 \mathrm{kBq} \mathrm{ml}^{-1}\right.$; Amersham). After an additional $18 \mathrm{~h}$ of culture, cells were harvested and tritium uptake was determined by a TopCount (Perkin-Elmer) scintillation counter.

Expression and purification of recombinant protein. Expression of recombinant proteins and deletion constructs was accomplished by amplifying from the cloned plasmid or genomic DNA with Pfu polymerase (Stratagene) and the following primers: (PA-4687), $\mathrm{Pa} 4687$ HIS [CAATTACATATGCATCACCATCACCATCACGATCAACCTGATGCAGACCAG] and Pa 4687 TERM [ATAGACTGAATTCACACACCAGTATTAGGCAG]; (PA-21693), Pa 21693 HIS [CAATTACATATGCATCACCATCACCATCACGCTGGTCCGACGGTAACCGTG] and Pa 21693 TERM [ATAGACTGAATTCTAGGTAACGGGCAGTCCCCGTCC]; (PA-21740), Pa 21740 HIS [CAATTACATATGCATCACCATCACCATCACGGTCATTCCTCCTCGACCTC] and Pa 21740 TERM [ATAGACTAAGCTTACAGGGCGCTCATTTGACTC]; (PA-5541), Pa 5541 HIS [CAATTACATATGCATCACCATCACCATCACGCTTCTAACGGGAACAGCT$\mathrm{CC}$ ] and $\mathrm{Pa} 5541$ TERM [TAGACTGAATTCGTTGTTTCCTGAGGCTGTCAG]; (PA-25957 FL), Pa 25957 HIS [CAATTACATATGCATCACCATCACCATCACAGCTCCAATAGGCCACGCTC] and Pa 25957 TERM [ATAGACTGAATTCGCCGATGGTGATCAGAATC]; (PA-25957 Amino), 25957 HIS and 25957 Amino TERM [ATAGACTGAATTCTACGGCTTCGGGCAGGAGCAAGCC]; and (PA-25957 Carb), Pa 25957 Carb HIS [CAATTACATATGCATCACCATCACCATCACTCCTGCCCGAAGCCGACTCC] and Pa 25957 Carb TERM [ATAGACTGAATTCTATCCCGTTGACGGAAGATC].

Primers contained restriction sites for cloning (bold) and a 6-histidine tag (italic) for protein purification (amino terminus). Amplification 
product was digested with the restriction enzymes NdeI and HindIII or EcoRI, depending on the primer set used, gel-isolated, and ligated to a pET17b plasmid vector (Novagen) previously cut with NdeI and HindIII or EcoRI and dephosphorylated with alkaline phosphatase (MB grade, Roche). The ligation mix was transformed into XL-1 Blue competent cells (Stratagene) and plasmid DNA was prepared for sequencing (Qiagen). Recombinant protein was expressed by transforming plasmid DNA into BL21 pLysS competent cells (Novagen) and inducing a single-colony cell culture with $2 \mathrm{mM}$ IPTG (Sigma); or by transforming plasmid DNA into BL21-AI competent cells (Invitrogen) and inducing a single-colony cell culture with $0 \cdot 2 \%$ L-arabinose (Sigma). Recombinant protein was recovered from cell lysate with Ni-NTA agarose beads (Qiagen), following the manufacturer's instructions, and dialysed in $10 \mathrm{mM}$ Tris/ $\mathrm{HCl} \mathrm{pH} \mathrm{4-10,}$ depending on predicted recombinant $\mathrm{pI}$ characteristics. Recombinant proteins were quality-checked for purity by SDS-PAGE followed by staining with Coomassie blue and by $\mathrm{N}$-terminal protein sequencing, and quantified with a Micro BCA assay (Pierce). Recombinants were assayed for endotoxin contamination with the Limulus assay (Bio Whittaker). Recombinant proteins were determined to be over $90 \%$ pure.

P. acnes recombinant protein antiserum preparation. Rabbit antiserum to recombinant antigens was prepared by injecting $200 \mu \mathrm{g}$ protein with $1 \mathrm{ml}$ incomplete Freund's adjuvant (IFA, Sigma) and $100 \mu \mathrm{g}$ muramyl dipeptide subcutaneously. Six weeks later, animals were boosted with $100 \mu \mathrm{g}$ protein in IFA followed by a final boost of $50 \mu \mathrm{g}$ administered intravenously 1 month later. Animals were killed 1 week after the final boost and sera were stored in aliquots at $-20^{\circ} \mathrm{C}$. IgG antibody was purified on protein A columns following the manufacturer's instructions (rProtein A Sepharose Fast Flow; Amersham Biosciences). All rabbit preimmune sera were screened by Western blotting against total $P$. acnes lysate, prior to selection for antibody production, to ensure that the rabbits had not been exposed to $P$. acnes and that there were no cross-reacting antibodies. All animal procedures were approved by the relevant local authorities.

ELISA analysis. Ninety-six-well EIA/RIA microtitre plates (Corning Costar no. 3369) were coated overnight at $4{ }^{\circ} \mathrm{C}$ with $100 \mathrm{ng}$ per well of the recombinant proteins. Plates were then aspirated and blocked with PBS containing $1 \%(\mathrm{w} / \mathrm{v})$ bovine serum albumin for $2 \mathrm{~h}$ at room temperature. This was followed by washing in PBS containing $0 \cdot 1 \%$ Tween 20 (PBST). Serum diluted in PBS containing $0 \cdot 1 \%$ BSA was added to wells and incubated for $30 \mathrm{~min}$ at room temperature, followed by washing six times with PBST and then incubating with secondary antibody-HRP conjugate (1/10000 dilution) for 30 min. Plates were then washed six times in PBST and then incubated with tetramethylbenzidine (TMB) substrate (Kirkegaard and Perry) for $15 \mathrm{~min}$. The reaction was stopped by the addition of $0.5 \mathrm{M}$ sulphuric acid and plates read at $450 \mathrm{~nm}$ using an ELISA plate reader (Biotek instrument EL311). Background values were determined by reading reactions that lacked the primary antibody step.

Subclass ELISA was performed as described above on 96-well EIA/RIA microtitre plates [Corning Costar no. 3369 (3699)], coated overnight at $4{ }^{\circ} \mathrm{C}$ with $250 \mathrm{ng}$ per well of the recombinant proteins, and probed with patient primary antibody at $1: 50$ dilution; secondary antibody (mouse IgG1 mAb anti-human IgG1, IgG2, IgG3 and IgG4; Calbiochem) at 1:1000; and tertiary antibody (goat anti-mouse IgG-HRP conjugate; Rockland Immunochemicals) at 1:10000 in PBST.

Immunoblot analysis. Recombinant antigens (50-200 ng per lane) were subjected to SDS-PAGE analysis using $15 \%$ polyacrylamide mini-gels (Invitrogen). The antigens were transferred to nitro-cellulose BA-85 (Schleicher \& Schuell) and blocked for $1 \mathrm{~h}$ at room temperature with PBS containing $1 \%$ Tween 20 . The blots were then washed three times for $10 \mathrm{~min}$ each in PBS containing $0 \cdot 1 \%$ Tween
20 (PBST). Next, the blots were probed for $1 \mathrm{~h}$ at room temperature with serum diluted 1:500 in PBST followed by $3 \times 10 \mathrm{~min}$ in PBST. The blots were then incubated for $30 \mathrm{~min}$ at room temperature with secondary antibody-HRP diluted 1:10000 in wash buffer and again washed $3 \times 10 \mathrm{~min}$ in PBST containing $0.5 \mathrm{M} \mathrm{NaCl}$. Finally, blots were incubated in chemiluminescent substrate ECL (Amersham) for $\sim 1 \mathrm{~min}$ and then exposed to X-ray film (XAR5) for 10-60 $\mathrm{s}$ as required.

Bacterial adherence assay. P. acnes clinical isolate GP-1 was cultured in BHI broth for 4 days at $37^{\circ} \mathrm{C}$ in an anaerobic chamber (ThermoForma). Cells were washed three times in PBS and resuspended in PBSTB (PBS with $0.5 \%$ BSA and $0.5 \%$ Tween 80 ) at $\mathrm{OD}_{600} 0 \cdot 4$. Ninety-six-well EIA/RIA plates (Corning no. 3369) were coated overnight with $5 \mu \mathrm{g}$ dermatan sulphate (ICN Biomedicals) in $100 \mu \mathrm{l}$ PBS per well, blocked with $2 \%$ BSA in PBS for $2 \mathrm{~h}$ at $4{ }^{\circ} \mathrm{C}$, and then washed three times in PBS. Aliquots $(600 \mu \mathrm{l})$ of diluted bacteria were pre-incubated for $1 \mathrm{~h}$ at room temperature in $2 \mathrm{ml}$ cryovials either with $60 \mu \mathrm{l}$ PBS (control), with $60 \mu \mathrm{l}$ dermatan sulphate at $5 \mu \mathrm{g}^{-1}$, or with purified rabbit IgG in PBS from animals immunized with recombinant $P$. acnes proteins $(10-20 \mu \mathrm{g}$ per well) or control protein $(20 \mu \mathrm{g}$ per well rabbit anti-chicken serum IgG: Rockland Immunochemicals). Cells were mixed gently by inversion and then $100 \mu \mathrm{l}$ of each sample was transferred to each of six wells of the pre-blocked microtitre plate. The plate was then sealed and incubated at $27^{\circ} \mathrm{C}$ with light rotation ( 80 r.p.m.) for 4 h. Finally, plates were washed three times gently by immersion in PBS and dried overnight at $37^{\circ} \mathrm{C}$. Bacterial adherence was quantified by staining with $100 \mu \mathrm{l}$ Gram crystal violet stain (Remel) for $30 \mathrm{~min}$, washing four times gently by immersion in PBS, and releasing stain with $100 \mu \mathrm{l} 30 \%$ acetic acid per well. Plates were read after $30 \mathrm{~min}$ with an EIA plate reader $\left(\mathrm{EL}_{\mathrm{X}} 800\right.$, Bio-Tek Instruments) at $570 \mathrm{~nm}$. Six replicates were carried out for each sample and experiments were repeated.

Sequence and phylogenetic analyses. A draft sequence of the $P$. acnes ATCC 6919 genome was commissioned from Genset (Evry Cedex, France) by Corixa Corporation. A total of $26 \times 10^{6}$ bases of DNA were sequenced, representing approximately 10 genome equivalents. An annotated database of ORFs was created using seven Genemark predictive models, as well as BlastP, Psort, SignalP, Pfamm, InterProScan and other bioinformatic applications. Multiple sequence alignments were performed using the CLUSTAL W algorithm (Thompson et al., 1994) and analysed with Jalview (Clamp et al., 2004). Whole-genome sequence comparison was carried out using the Artemis Comparison Tool (ACT: http://www.sanger.ac.uk/ Software/ACT/).

\section{RESULTS}

\section{Expression screening and characterization of antigens}

Three genomic lambda expression libraries (generated from P. acnes isolates type IA ATCC 6919, type IB PA-1 and type II PA-2) were each screened with two pools of human serum from five individuals with a history of moderate to severe acne (pool 1, acne-positive) and five individuals with no acne or mild acne (pool 2, acne-negative). Following incubation with the serum, 91 of the lambda library plaques reacted with anti-human $\operatorname{IgG}, \operatorname{IgA}$ and $\operatorname{IgM}$ secondary antibody used in combination (Table 1). The human sera reacted predominantly with four antigens PA-5541, PA-25957, PA-4687 and PA-21693 (GenBank accession numbers DQ469874, DQ469873, DQ469871 and 
Table 1. Number of clones reacting with serum from acnepositive and acne-negative donors using a combination of anti-human $\lg$, $\lg \mathrm{A}$ and $\lg \mathrm{M}$ secondary antibodies

\begin{tabular}{|lcc|}
\hline & \multicolumn{2}{c|}{ No. of positive clones } \\
\cline { 2 - 3 } & Acne-negative donors & Acne-positive donors \\
\hline Total & 43 & 48 \\
ORFs & & \\
PA-4687 & 9 & 0 \\
PA-21693 & 6 & 2 \\
PA-25957 & 5 & 11 \\
PA-5541 & 3 & 1 \\
\hline
\end{tabular}

DQ469870, respectively). Fifty-four per cent of the 43 clones that reacted with the acne-negative serum screen and $29 \%$ of the 48 clones that reacted with the acne-positive serum were positive for one of these four antigens. Further screening with anti-human IgA secondary antibody alone led to the identification of another 107 clones, and screening with a rabbit polycolonal antiserum raised to $P$. acnes cell lysate (PA-1 and -2) to another 42 . Approximately $30 \%$ of the total 240 clones examined encoded one of the four antigens identified in the combined anti-human IgG, A and M screen.
All 240 plasmid clones derived from the serological expression screening above were induced to synthesize protein and then screened with human donor $\mathrm{T}$ cell lines generated by stimulation with total $P$. acnes antigens. Of the 240 plasmid clones assayed, 33 were positive in the proliferation assays and $75 \%$ of these positive clones contained the ORFs PA-25957 (13 clones), 5541 (3 clones), 4687 ( 2 clones) or 21693 ( 7 clones). T cell line A demonstrated strong reactivity to PA-25957 and PA-5541 and weak reactivity to PA-21693 and PA-4687 whereas T cell line B exhibited strong reactivity only to clones expressing PA21693 and PA-25957. Examples of two proliferation and IFN- $\gamma$ assays performed on 48 of the induced plasmid clones, illustrating the reactivity of PA-21693, PA-5541 and PA-25957, are presented in Fig. 1.

The four antigens are all predicted to be surface/excreted proteins based upon sequence similarity with known antigens from other bacteria and cleavable signal sequences. All four antigens have LPXTG motifs towards the carboxyterminus, but with the exception of PA-21693, they lack the hydrophobic domain and positively charged tail characteristic of the sorting signal (Pallen et al., 2001). They represent two categories of proteins: PA-4687 and PA-21693 are similar to each other (37\%) and also to the htaA-encoded antigen of Corynebacterium diphtheriae and C. ulcerans
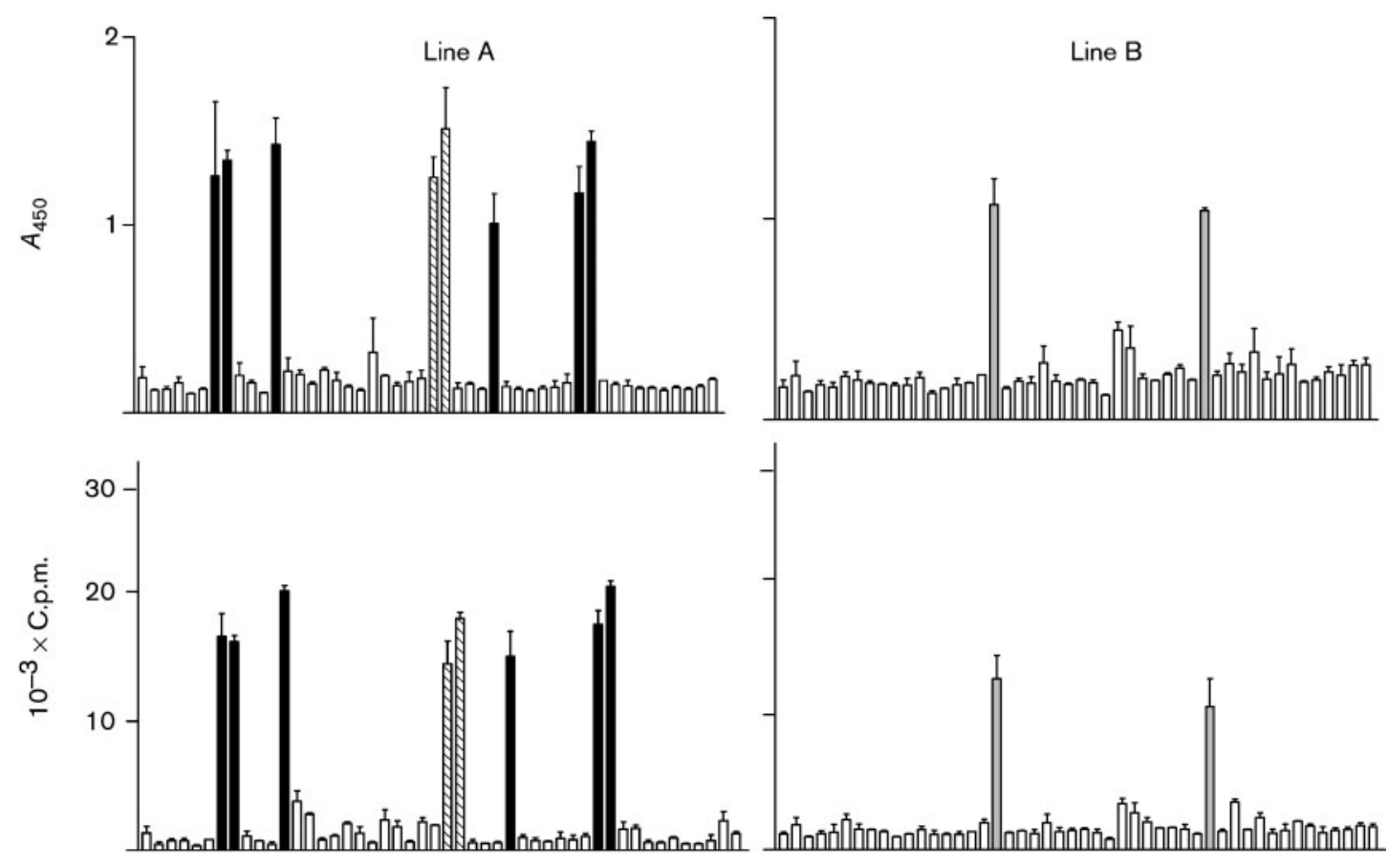

Fig. 1. Recognition of serologically identified $P$. acnes antigens by $P$. acnes-specific $T$ cell lines. $P$. acnes-specific $T$ cell lines generated from two different healthy donors with no history of inflammatory acne (lines $A$ and $B$ ) were used to screen for reactivity with $E$. coli containing cloned $P$. acnes genes, identified by serological screening. T cell reactivity was measured by IFN- $\gamma$ production (top panel) and cell proliferation (bottom panel). Bars represent means of duplicate values. Values greater than $3 \mathrm{SD}$ above the control ( $\mathrm{T}$ cells incubated with no $E$. coli clone) were considered stimulatory. Positive clones were sequenced and identified as PA-25957 (black bars), PA-5541 (hatched bars), or PA-21693 (grey bars). 
(Fig. 2); while PA-5541 and PA-25957 are highly similar to each other $(68 \%)$ and have some similarity with the M-like proteins of Streptococcus equi (see Fig. 4).

\section{Analysis of HtaA-like proteins and characterization of a putative iron/haemin transport system}

The $C$. diphtheriae htaA gene, although of unknown function, is a member of the hmuTUV gene cassette that encodes a haemin ABC transporter system (Schmitt \& Drazek, 2001). Additional members of this cassette are hmuT, similar to PA-21740 (GenBank accession number DQ469872) and encoding a putative haem-binding lipoprotein; $h m u U$, similar to PA-21695 (GenBank accession number DQ767876) and encoding a predicted permease; and $h m u V$, similar to PA-21788 (GenBank accession number DQ767877) and encoding a predicted ATP-binding protein (Fig. 2a). These genes also share some homology with the Streptococcus pneumoniae iron ABC transport

(a) Gene Locus

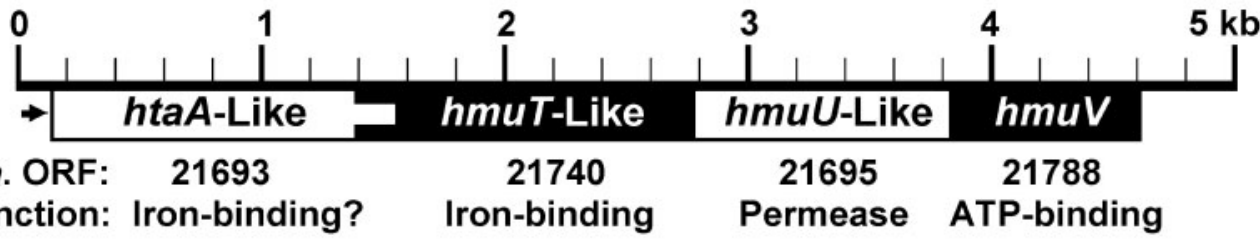

(b) Homology

$\begin{array}{lcccc}\text { \% w/C.d.* } & 36 \% & 51 \% & 54 \% & 46 \% \\ \% \text { w/C.u. } & 34 \% & 50 \% & 52 \% & 43 \% \\ \% \text { w/S.p. } & ? & 26 \% & 26 \% & 31 \%\end{array}$

(c) Promoter Region

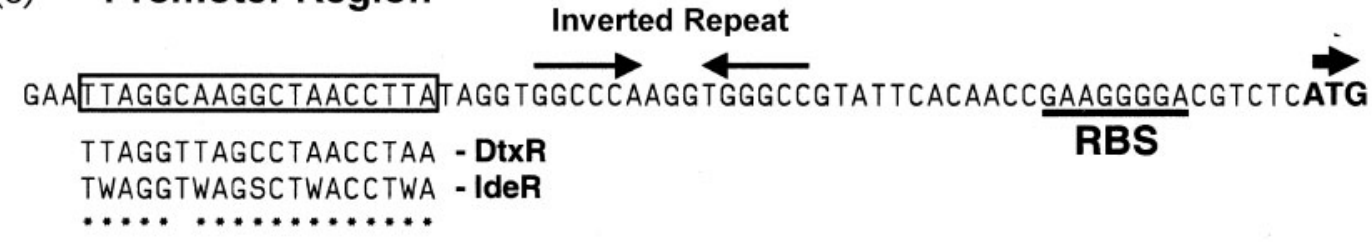

(d)

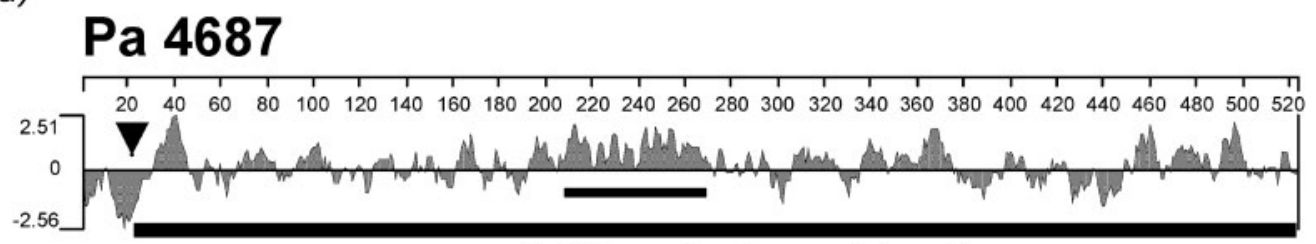

Pa 21693

Full-Length Recombinant

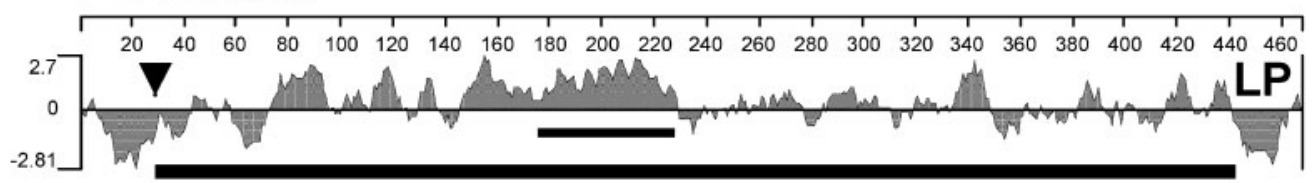

Full-Length Recombinant

Fig. 2. Characterization of antigens $P A-4687$ and PA-21693. (a) Schematic of the $P$. acnes Hmu-like gene locus showing organization, ORF number and proposed function. (b) Percentage similarity of the $P$. acnes ABC antigens with (\% w/) their homologues from Corynebacterium diphtheriae (C.d.), C. ulcerans (C.u.) and Streptococcus pneumoniae (S.p.). A question mark indicates that no homologue was found in the database. (c) Sequence of the $P$. acnes promoter region for the PA21693 gene locus with homology, indicated with dots, to the C. diphtheriae (DtxR) and M. tuberculosis (IdeR) regulatory sites. An inverted repeat is indicated by arrows and the proposed ribosome-binding site (RBS) is underlined. The ATG start codon is marked in bold and with an arrow. (d) Hydrophobicity plots for antigens PA-4687 and PA-21693 showing hydrophobic leader sequences (arrowhead), hydrophilic repeat regions (thin underline) and hydrophobic LPxTG site (LP). The regions of recombinant protein production are shown by a bold underline. 
system, which includes genes encoding an iron-binding protein SP1872 (the piuA gene), the permeases SP1870 and SP1869, and the ATP-binding protein encoded by SP1871 (Fig. 2a).

ORFs PA-4687 and PA-21693 encode predicted antigens with an amino-terminal cleavable signal sequence and a hydrophilic degenerate repeat in the mid region consisting of nine units of 6 aa each for PA-4687 (PKPSVX), and four or five units of 6 aa for PA-21693 (PSKQXX) (Fig. 2d). Antigen PA-21693 has a carboxy-terminal sortase-sorting signal that includes the LPXTG motif followed by a hydrophobic domain and a tail of positively charged residues (Schneewind et al., 1995). Antigen PA-4687, however, contains only a carboxy-terminal LPXTG motif followed by a single amino acid residue (valine). It does, however, contain a predicted transmembrane region at residues $427-451$.

Both PA-21693 and PA-21740 are members of a proposed $\mathrm{ABC}$ iron transport locus (Fig. 2a), while PA-4687 does not appear to be associated with a similar gene locus (data not shown). When purified under standard conditions, both rPA-21693 and rPA-21740, but not PA-4687, were red in colour and both showed a peak absorbance at $405 \mathrm{~nm}$ indicating a probable association with iron. The stability of rPA-21693 was improved by production under reducing conditions (purified in the presence of 2-mercaptoethanol, and dialysed in the presence of $\mathrm{L}$-cysteine). This resulted in a stable and colourless protein. We also examined the genome sequence for regulatory sequences, such as the $C$. diphtheriae DtxR (Qian et al., 2002) and the Mycobacterium tuberculosis IdeR operator sequences (Rodriguez et al., 2002). The promoter region of PA-21693, but not PA-4687, contains a putative regulatory region (Fig. 2c). In addition, upon searching the translated $P$. acnes genomic sequence with the DtxR and IdeR protein sequences, we found a predicted protein sequence (PA-16990) with a high homology to DtxR ( $46.5 \%$ overall and $74.6 \%$ at the amino-terminal 116 aa, with $C$. diphtheriae), again indicating that the PA-21693 operon is iron regulated. The sequence of PA-16990 was identical to the P. acnes KPA171202 DtxR-like repressor: GenBank accession AAT82237, locus PPA0485.
We examined the potential regulation by iron of PA-4687 and PA-21693 by culturing $P$. acnes clinical isolates GN-3 and GP-1 in a defined medium, with or without added iron. Immunoblot analyses indicated that this operon is regulated by iron concentration (Fig. 3).

\section{Analysis of M-like proteins and attachment to host molecules}

Although PA-5541 and PA-25957 are only weakly similar to the M-Like protein of S. equi (30\% over 306 residues; GenBank AAP22285), they do have in common a cleavable signal sequence, a similar pattern of degenerate repeats, a hydrophilic proline-rich repeat near the carboxy-terminus (PTPT vs PEPK) and LPXTG motifs (Fig. 4). Both antigens also contain two or three transmembrane helices in their mid-regions.

Frick et al. (2003) demonstrated that the Streptococcus pyogenes $\mathrm{M}$ proteins, in addition to their interaction with factor $\mathrm{H}$ of the complement cascade leading to resistance to phagocytic uptake, mediate binding to various forms of glycosaminoglycans including dermatan sulphate, heparin sulphate and heparin. We therefore studied the potential for PA-5541 and PA-25957 to mediate binding to host molecules by use of a 96-well microtitre tray adherence assay. Weak binding of clinical isolate GP-1 to dermatan sulphate was observed. When the cells were pre-incubated with either free dermatan sulphate, purified IgG raised against a whole-cell lysate of $P$. acnes, anti-recombinant PA5541 or anti-PA-25957 antibody, binding was significantly reduced (Fig. 5). Pre-incubation of the cells with an irrelevant IgG had little effect on binding when compared to a control treated with PBS only. The binding of isolate GP-1 was affected to a lesser degree by anti-PA-4687 and anti-PA-21693 antisera. Binding to human collagen I and fibronectin could be blocked with an anti-P. acnes lysate but not significantly with the anti-recombinant PA-5541 or anti-PA-25957 (data not shown).

\section{Sequence analysis of $\boldsymbol{P}$. acnes clinical isolates}

To determine the sequence conservation of ORFs PA-4687, PA-21693, PA-5541 and PA-25957 among clinical isolates of

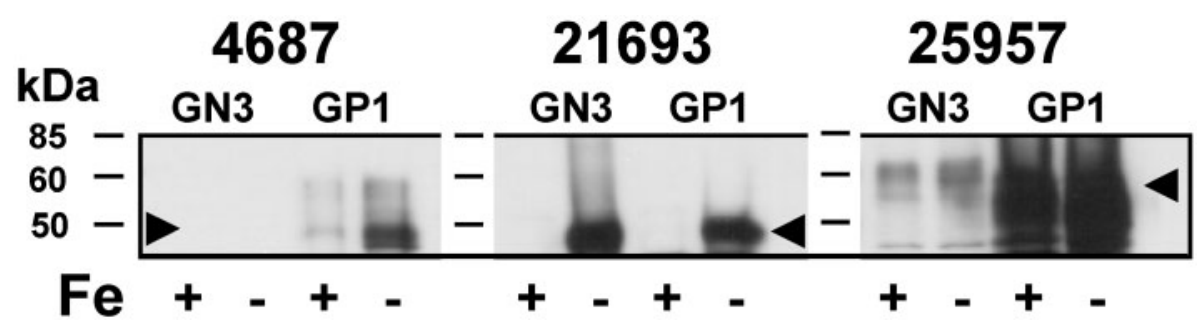

Fig. 3. Effect of iron on the expression of PA-21693. P. acnes clinical isolates GN-3 and GP-1 were cultured in the presence $(+)$ or absence $(-)$ of iron. Cells were lysed and proteins were transferred to nitrocellulose and probed with rabbit anti-rPA4687, anti-rPA-21693 and anti-rPA-25957 serum. Molecular mass markers are shown on the left. 
(a)

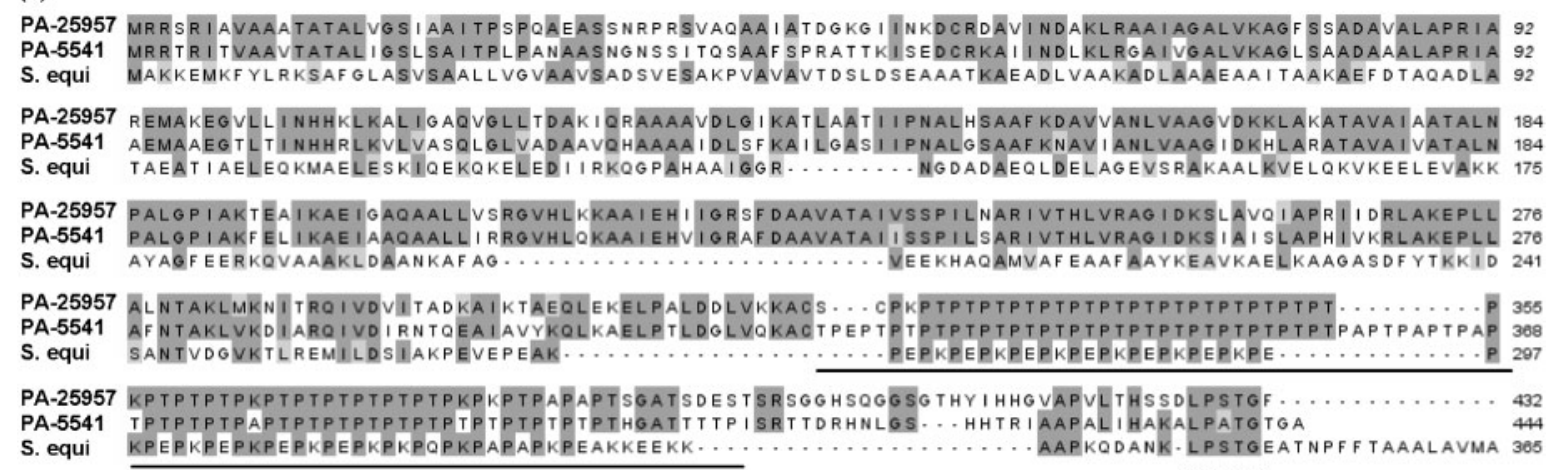

(b)

$\begin{array}{ll}\mathrm{Pa} & 25957 \text { Repeat Region }\end{array}$
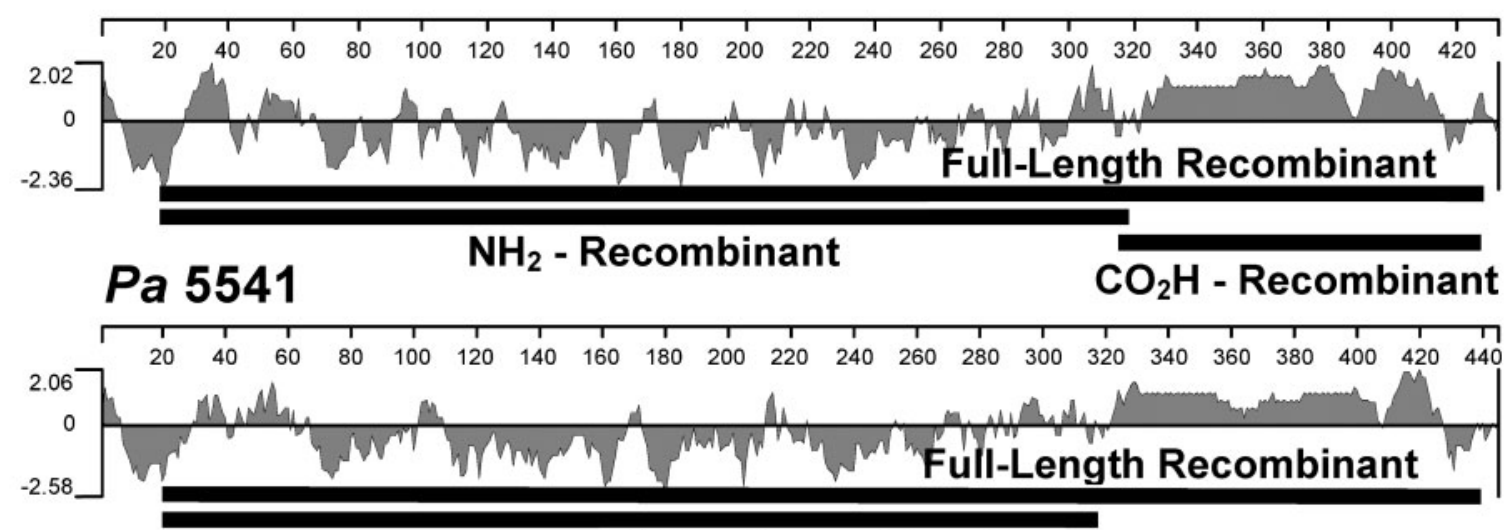

S. equi M-Like

$\mathrm{NH}_{2}$ - Recombinant

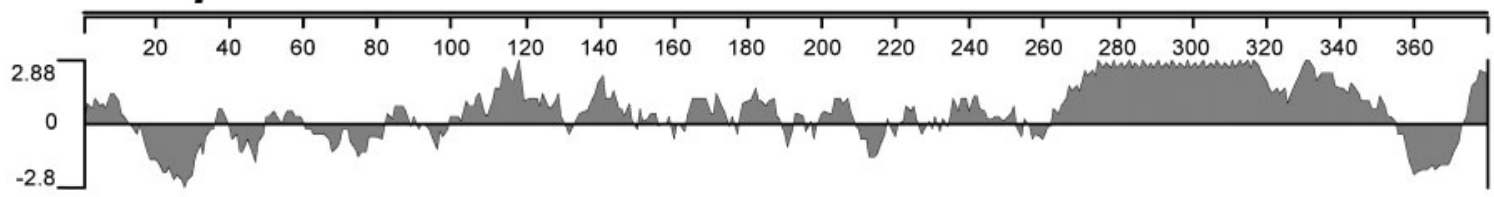

Fig. 4. Comparison of sequence similarity and hydrophobicity for antigens PA-25957 and PA-5541. (a) Sequence similarity alignment for antigens PA-25957 and PA-5541 and the S. equi M-like protein showing amino acid identities in grey. Note the proline-rich region (solid underline) and LPXTG motif (dotted underline). (b) Hydrophobicity profiles of antigens PA-25957 and PA-5541 and the $S$. equi M-like antigen. Underlined regions indicate sections of the antigens that were used in constructs for recombinant protein expression.

types IA, IB and II, we amplified each ORF using conserved flanking primers and standard PCR protocols from $20 \mathrm{P}$. acnes isolates from various geographical regions and directly sequenced the resulting product to avoid random mutations introduced during amplification or culture. In addition, we compared the homologous genes in the $P$. acnes genomic sequence AE017283 from strain KPA171202 (Bruggemann et al., 2004). The equivalent putative annotated protein in these regions in KPA171202 for PA-25957 is PPA 2127; PA 5541, PPA 2210; PA-21693, PPA0779; PA-21740, PPA0780; and PA-4687, PPA0786.

Alignments of the predicted polypeptide sequences indicated a high degree of sequence conservation with the HtaA-like
PA-21693, showing a similarity of $98 \cdot 3-99 \cdot 8 \%$ over the entire polypeptide length. The differences were generated by single-nucleotide polymorphisms.

The predicted polypeptide sequences for PA-4687, PA-5541 and PA-25957, however, have frameshifts near the putative signal peptide cleavage site and variable repetitive sequences towards the mid-region and carboxy-terminus in some isolates. In the HtaA-like PA-4687, the insertion of a T residue downstream of, and close to, the signal peptide cleavage site has resulted in a frameshift in the type IB clinical isolates, introducing a stop codon into the PA-4687 equivalent reading frame. Scrutiny of the KPA171202 (type IB) sequence revealed annotation of a putative conserved 


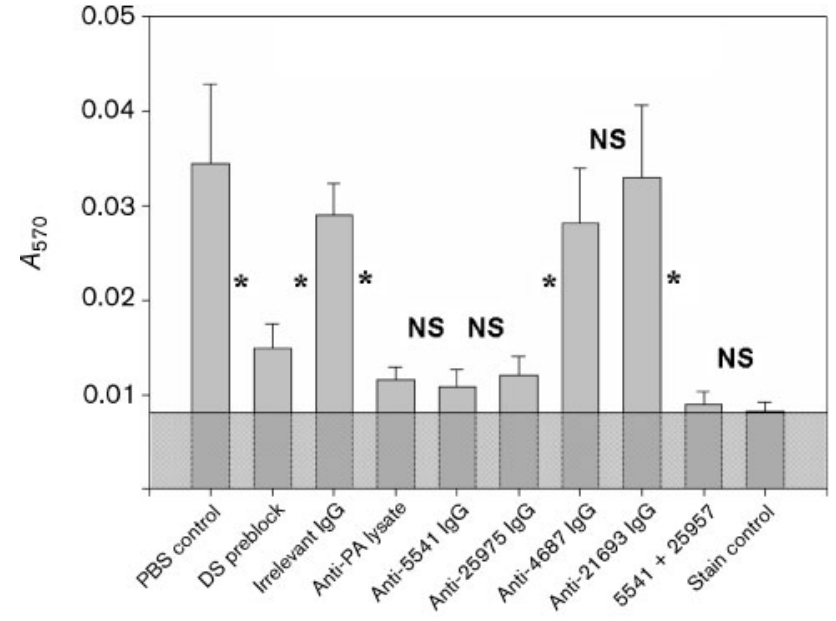

Fig. 5. Adherence of $P$. acnes clinical isolate GP-1 to dermatan sulphate determined by $A_{570}$ after crystal violet staining of adherent bacteria. Washed cells were preblocked with either PBS (control), dermatan sulphate (DS), irrelevant IgG, anti-PA1 whole-cell lysate $\operatorname{lgG}$, anti-rPA-5541 lgG, anti-rPA-25957 lgG, anti-rPA-4687 lgG, anti-rPA-21693 lgG, and pooled antirPA-5541 and anti-rPA-25957 lgG. Wells coated with dermatan sulphate but not incubated with bacteria were used as a stain control. Significant differences between groups $(P \leqslant 0.05)$, as determined by Student's $t$ test, are indicated by asterisks between the respective pairs; non-significant differences $(P>0.05)$ are indicated by NS between the respective pairs.

protein of approximately $41 \mathrm{kDa}$ (with an in-frame LPXTG motif) downstream of this (PPA0786), generated by a second potential start codon within the PA-4687 CDS. Type IB and type II isolates have different numbers of deletions in the PKPSVX repeat region. Within the four type II isolates, three different sequences were observed in this region, giving rise to proteins 332, 499 and 505 aa in length with predicted molecular masses of $34 \cdot 8,51 \cdot 5$ and $52 \cdot 1 \mathrm{kDa}$ respectively. The sequence alignments are shown in supplementary Fig. S1, available with the online version of this paper.

In the predicted M-like protein sequence PA-5541, variable numbers of $C$ nucleotides in the $C_{n} T_{n}$ region immediately upstream of the predicted signal cleavage site give rise to a frameshift; for example, $\mathrm{C}_{6} \mathrm{TC}_{4}$ in type IA ATCC 1619; $\mathrm{C}_{5} \mathrm{TC}_{4}$ in type IB PA-13; and $\mathrm{C}_{3} \mathrm{TC}_{5}$ in type II PA-3. In KPA171202 (PPA2210) the frameshift puts an alternative start codon and signal peptide into frame with the downstream protein. A similar frameshift was also observed in two of our type IB clinical isolates, PA-13 and GN-3. The PTrepeat region was variable among isolates of the same type when compared to the ATCC 6919 sequence, generating predicted proteins from 411 to 444 aa in length ranging in predicted molecular mass from $42 \cdot 0$ to $45 \cdot 2 \mathrm{kDa}$. The sequence alignments are shown in supplementary Fig. S2, available with the online version of this paper.
The M-like PA-25957 sequence also contained frameshifts in a $C_{n} T_{n}$ motif in the leader sequence, with each of the three possible reading frames evident in different isolates (Fig. 6a, b). These frameshifts can give rise to two possible leader sequences. In addition, in our IB clinical isolates, PA1 and PA-13, and KPA171202, the start codon ATG is replaced with ATA. There is, however, an alternative ATT start site upstream (Fig. 6b). There is no start site upstream of the $\mathrm{C}_{n} \mathrm{TC}_{\mathrm{n}}$ region in the third frameshift, although there are a number of start codons downstream of the predicted cleavage site. Different $P$. acnes isolates of the same type exhibited different frameshifts (Fig. 6b). Four of the five type II isolates (PA-2, PA-3, PA-5 and PA-6) also contained a frameshift in a C-rich region at the extreme carboxyterminus that eliminates the LPXTG motif (shown for PA-2 in Fig. 6d). As with PA-5541, the PT-repeat region was variable when compared to the ATCC 6919 sequence (Fig. 6c), generating predicted proteins from 401 to 434 aa in length ranging in predicted molecular mass from $40 \cdot 9$ to $44 \cdot 2 \mathrm{kDa}$. The repeat regions in all four antigens are hydrophilic and are predicted to be highly antigenic (Figs 2 and 4).

As a control for PCR fidelity in this study, genomic DNA from the ATCC 6919 isolate was used as a template for PCR, and the resulting sequence was compared to the corresponding Corixa Corporation $P$. acnes genomic sequence that was derived from the ATCC 6919 isolate. In all comparisons, the ATCC 6919 isolate PCR product sequence was identical to the ATCC 6919 genomic sequence from the Corixa P. acnes database.

\section{PA-4687, PA-21693, PA-5541 and PA-25957 expression and immunoblotting analyses}

PAGE and immunoblotting analyses of recombinant proteins using rabbit anti-recombinant antiserum indicated that there was cross-reactivity between the two M-like proteins PA-5541 and PA-25957, which have an overall similarity of $65 \%$. In addition the anti-HtaA like PA-4687 antiserum cross-reacted with the two full-length recombinant M-like proteins, but not with amino-terminal recombinant fragments that lacked the PT repeat regions. There was no cross-reaction between the anti-HtaA-like 21693 antiserum and the other recombinant proteins (Fig. 7). The higher molecular mass of these proteins on SDS-PAGE when compared to the predicted molecular mass may be due to their high proline content. For example, the Mycoplasma pneumoniae M129 protein was named P65 because of its apparent molecular mass of $65 \mathrm{kDa}$ as estimated by SDS-PAGE. However, DNA sequence analysis revealed an ORF encoding a protein with a molecular mass of $47034 \mathrm{Da}$. This discrepancy was explained by the unusual amino acid composition of this protein, including a $13.5 \%$ proline content (Proft et al., 1995). The proline content of PA-25957, $-5541,-4687$, and -21693 is $10.9 \%, 11.9 \%$, $7 \cdot 1 \%$, and $6 \cdot 8 \%$ respectively.

Expression in type IA (ATCC 6919, GP-1) and type IB (PA-1, GN-3) clinical isolates was analysed by immunoblotting 
(a)

Isolate

ATCC 1619
KPA171202
PA-1
GN-3
PA-2
PA-3

(b)

Type

Type 1A

Type 1B

PA-1

GN-3

Isolate

C-rich region

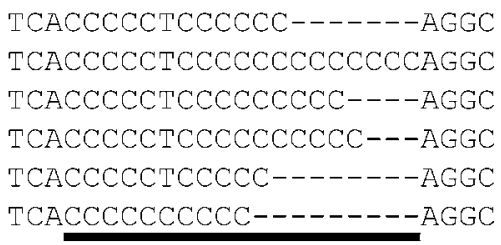

TCACCCCCCCCCC---------AGGC

Type II PA-2

PA-3

\section{Region upstream of putative cleavage site
+}

ATCC6919 MRRSRIAVAAATATALVGSIAAITPSP nQAEASSNRPR

$+$

IRRSRIAVAAATATALVGSIAAITPSP ${ }_{n}$ QAEASSNRPR EKQYVGQELLSLLRRLLRWSDQSQQSP QAEASSNRPR

$+$

NASVKNCCRCCDGYCAGRINRSNHPLP

EKQCVGQELLSLLRRLLRWSDQSQQSP QAEANSNRPR

(c)

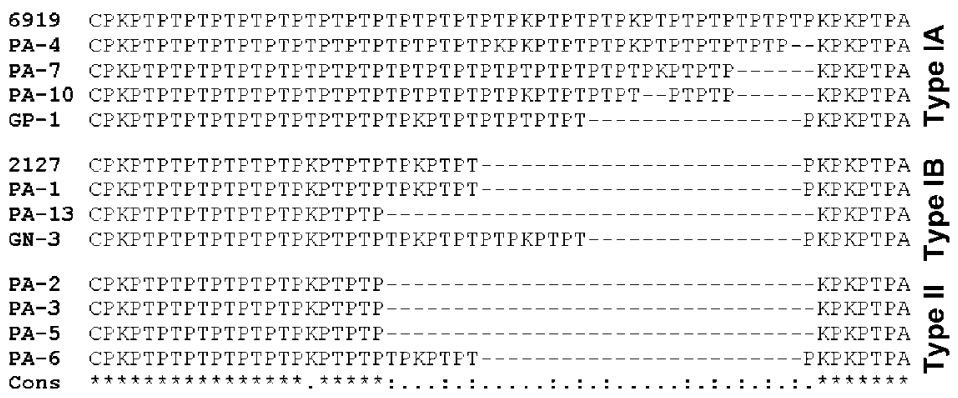

(d)

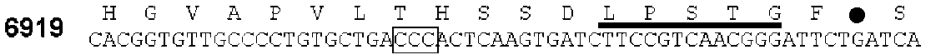

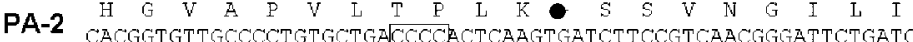

Fig. 6. Variability in antigen PA-25957 DNA and translated protein sequences. (a) Examples of the variable $\mathrm{C}$-rich region (underlined) upstream of the putative signal peptide cleavage site. (b) Alternative regions upstream of the putative signal peptide cleavage site generated by insertion/deletion of $\mathrm{C}$ residues as illustrated in (a). Each of the three possible reading frames is represented in the range of clinical isolates studied. The putative cleavage site is indicated by an arrowhead; putative start codons are indicated by '+'. Type IA: PA-4, 7, 9, 10, Z-4, $7,8, \mathrm{GN}-1$ and 2 , and GP-1 and 2 are in the same frame as ATCC 6919; type IB: $\mathrm{PA}-13$ is in the same frame as PA-1 and KPA171202 is in the same frame as GN-3; type II: PA-5 and 6 are in the same frame as PA-2. $P_{n}$ indicates a polyproline region where $\mathrm{n}$ is between 1 and 6 proline residues. (c) Alignment of the PA-25957 repeat sequence, beginning at amino acid 324 of the ATCC 6919 sequence, showing deletions (-) and variability among representatives of the three phylogenetic clusters (IA, IB and II). Identical residues are indicated by an asterisk and conserved residues by a period. Additional isolates showing similar patterns to type IA include PA-9 and Z-4, 7 and 8 . (d) Alignment of the carboxy-terminal region of PA-25957, beginning at residue 415 , showing a frameshift in type II isolate PA-2 that results in a truncation that eliminates the LPXTG motif (underlined). The variable poly-C region is boxed and stop codons are indicated by $\boldsymbol{\bullet}$. using soluble material from whole-cell lysates, insoluble cell envelope material and cell-free culture supernatants (Fig. 8) with anti-recombinant protein antisera. Immunoblot results were then compared to the corresponding sequence data from isolate PCR analysis. Where the sequence data predicted an in-frame signal sequence, multiple labelled bands were evident in the immunoblot in cell envelope preparations containing cell wall and membrane (Fig. 8). Labelled bands were also observed with the anti-r21693, anti-r5541 and anti-r25957 antiserum in soluble cell lysate fraction and concentrated supernatant. Where an in-frame signal sequence was not predicted, single bands of molecular mass in the region of $40-43 \mathrm{kDa}$ were evident in cell envelope material (Fig. 8), but not in concentrated supernatant or soluble whole-cell lysate. Scrutiny of the sequences of these genes indicated that there are alternative start codons downstream which could potentially generate proteins of lower molecular mass. In the case of PA-4687 it may be that band observed in the immunoblot equates to the predicted $41 \mathrm{kDa}$ product generated from the CDS with the GTG start site downstream of the frameshift region (PPA0786 in KPA181202: Fig. 6b).

\section{Human immune reaction to recombinant antigens}

Because both PA-5541 and PA-25957 contain a region of PT-repeat sequence near the carboxy-terminus that is predicted to be highly antigenic and because of the serological response to PA-25957 in acne-positive patients, we mapped the PA-25957 epitopes recognized by antibody subclasses in the serum of acne-negative (mild or no acne) individuals and acne-positive donors (moderate to severe acne). Recombinant proteins (full-length, amino-terminal to PT-repeats, and PT-repeats plus carboxy-terminus) were purified and analysed by ELISA with serum from acnenegative and acne-positive individuals. Although the reactivity was weak, the full-length molecule was recognized 


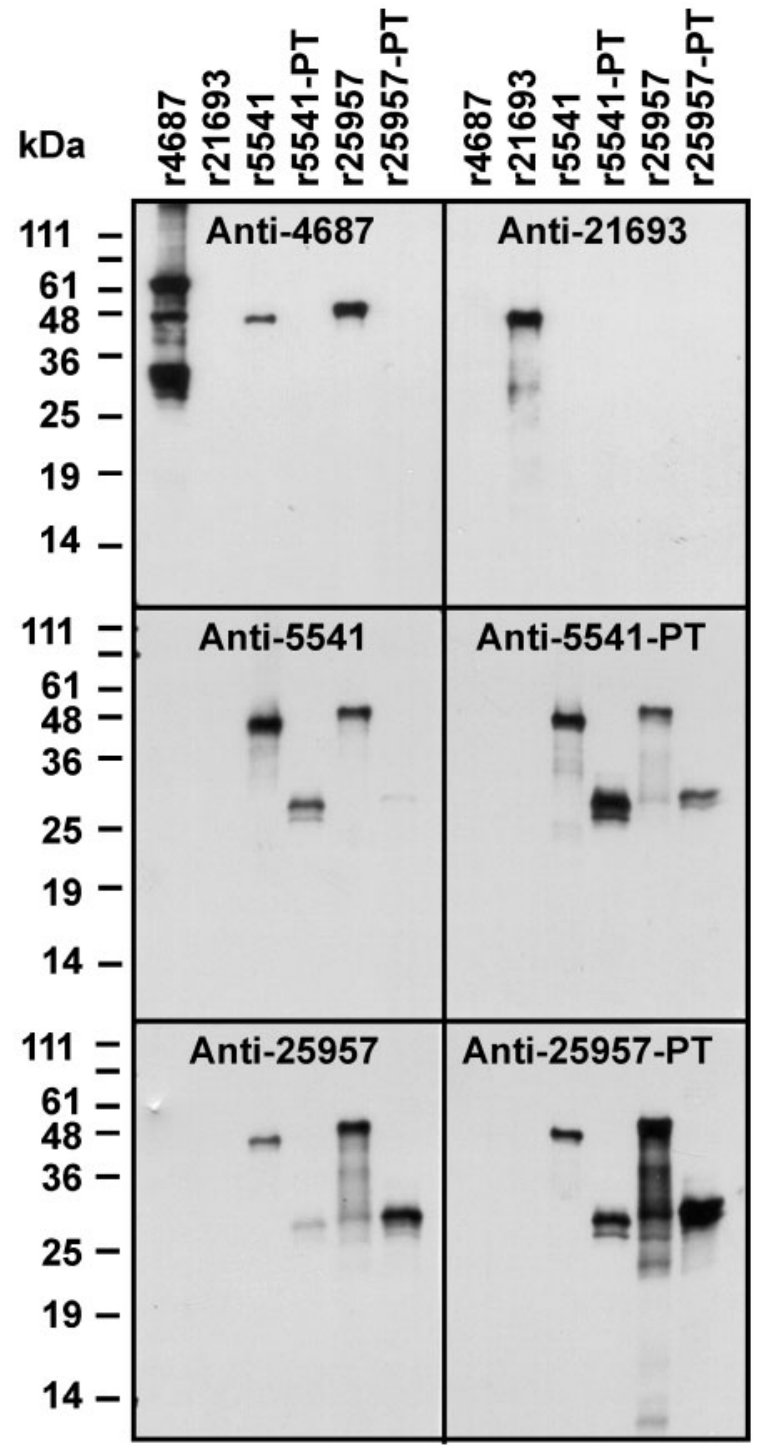

Fig. 7. Immunoblots of recombinant proteins r4687, r21693, r5541, r25957, and the amino-termini of r5541 and r25959 that lack the carboxy-terminal PT (-PT) repeats. Identical blots were probed with rabbit antiserum to the same recombinant proteins to reveal any cross-hybridization of antibody to antigen. Molecular mass standards are shown in kDa.

predominantly by $\operatorname{IgG} 3$ in acne-negative individuals and predominantly by IgG1, IgG3 and IgG4 in acne-positive individuals (Fig. 9, FL). When the amino-terminus of the molecule (without PT-repeats) was examined, little or no reactivity to this fragment was seen in the acne-negative sera while predominantly IgG1 and IgG4 antibodies in the acnepositive sera were reactive with this fragment (Fig. 9, $\mathrm{NH}_{2}$ ). The carboxy-terminus of the molecule, including PTrepeats, was recognized predominantly by $\operatorname{IgG} 2$ and $\mathrm{IgG} 3$ in the acne-negative patients and weakly recognized by IgG2 and IgG3 in the acne-positive sera. Little or no IgG4 reactivity was seen in these sera (Fig. 9, PT).
The endotoxin-free PA-5541 and PA-25957 recombinant proteins (full-length and amino-terminal to PT-repeats) were also assayed in proliferation assays using $P$. acnesspecific $\mathrm{T}$ cell lines (Fig. 10). The full-length recombinants and the amino-terminal fragments of antigens PA-25957 and PA-5541 were positive in proliferation assays. No proliferation was seen when the carboxy-terminal fragment (containing PT-repeats) of PA-25957 was used. A similar recombinant protein representing the carboxy-terminus of PA-5541 was not produced.

\section{DISCUSSION}

In this study we cloned antigens from $P$. acnes expression libraries. The dominant $\mathrm{B}$ cell and $\mathrm{T}$ cell antigens identified fell into two groups: antigens PA-4687 and PA-21693 are related to the Corynebacterium htaA gene in the hmu ABC transport locus; and antigens PA-25957 and PA-5541 have weak similarity with and similar features to the M-like protein of Streptococcus equi. These four antigens were cloned from expression screening with pools of serum from both acne-negative and acne-positive patients. However the htaA-like clones were more abundant from the acnenegative serum screens. All four antigens contained predicted cleavable leader sequences and potential cellwall-binding LPXTG motifs, suggesting that they could be cell surface or secreted antigens. The proteins were detected in both concentrated cell-free supernatants and insoluble cell envelope fractions, indicating that these proteins may be both cell surface associated and secreted. Only the HtaA-like PA-21693, however, contains the membrane-spanning domain and charged carboxy-tail characteristic of sortase substrates (Pallen et al., 2001). One putative sortase A gene, PPA0777, is present in the KPA171202 P. acnes genome (Bruggemann et al., 2004) but the equivalent locus in ATCC 6919 is disrupted by two frameshifts. It may be that cell wall anchoring is mediated by another enzyme such as the lpxtgase described by Lee et al. (2002). The DNA sequence of PA21693 was highly conserved amongst ATCC 6919 and KPA171202 and 14 clinical isolates examined, including representatives of types IA, IB and II P. acnes, with sequence differences arising from single nucleotides. The htaA-like PA-21693 is within a putative operon with similarity to the iron-regulated hmuTUV gene cassette that encodes a haemin $\mathrm{ABC}$ transporter system in $C$. diphtheriae. The gene cassette is regulated by binding of the diphtheria toxin repressor (DtxR) to a specific sequence in the promoter region. On comparison of the homologous $P$. acnes promoter sequence, a similar domain was found. A putative homologous DtxR-like protein with $46 \%$ identity is present in the P. acnes ATCC 6919 genome sequence. Comparison of expression of the HtaA-like PA-21693 and M-like PA-25957 in the presence and absence of iron indicated that only PA21693 was iron repressed. The differential regulation of this protein based on exposure to iron could be important in host immune responses, depending on the location of the bacteria (i.e. skin surface or within comedone or tissue). Antigen PA-21693 might be expressed when bacteria are 

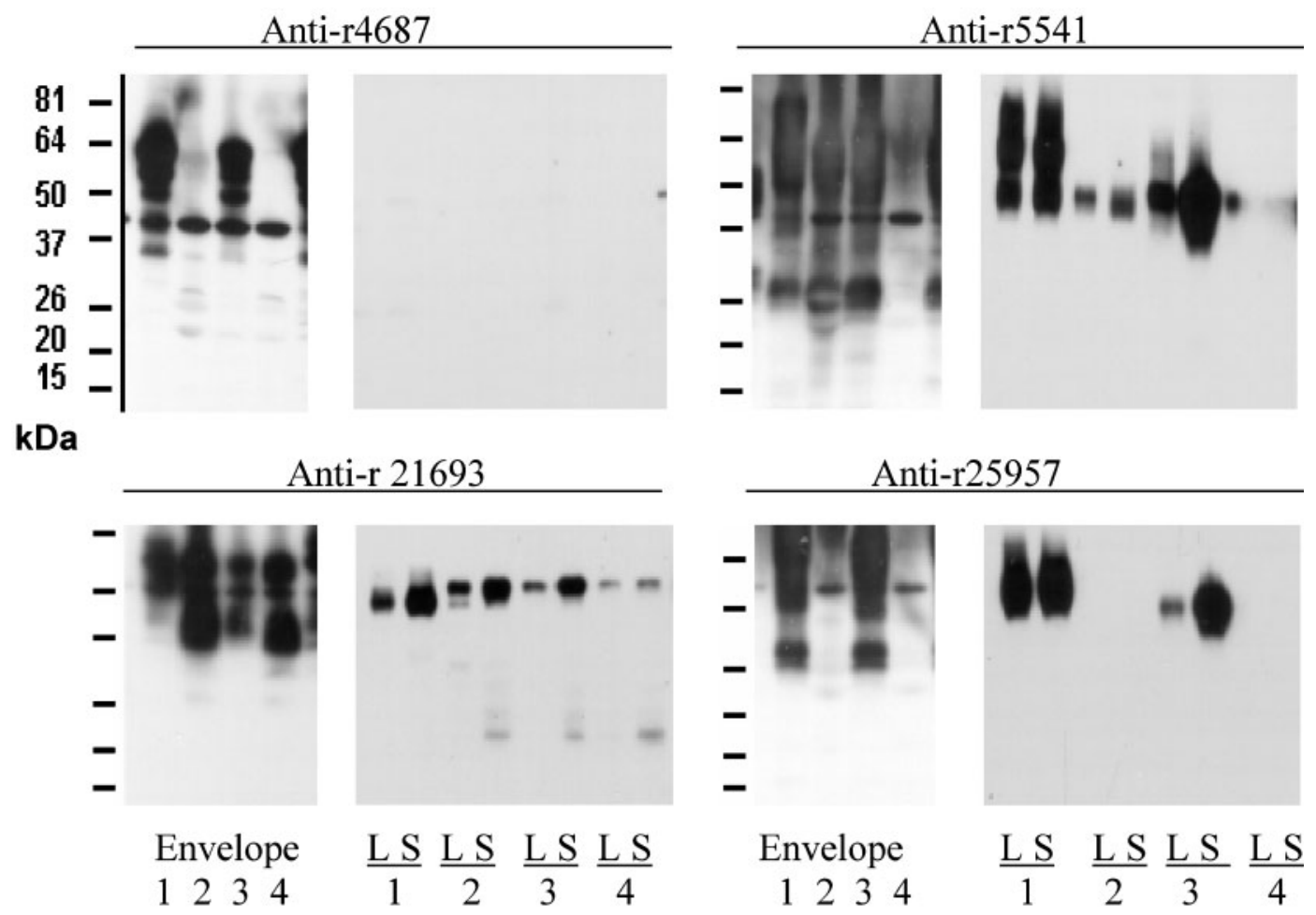

Fig. 8. Immunoblots showing expression of antigens in $P$. acnes clinical isolates. Cell wall and membrane fraction (envelope), soluble lysate fraction $(\mathrm{L})$ and concentrated culture supernatant $(\mathrm{S})$ preparations from $P$. acnes clinical isolates ATCC 6919 (1), GN-3 (2), GP-1 (3) and PA-1 (4). Blots were probed with rabbit antiserum specific for recombinant proteins r4687, r21693, r5541 and r25957. Molecular mass markers are shown in kDa.

located on the skin surface or follicles, and not when located in comedones or in tissue. The predicted functions for PA21693 of iron binding and PA-21740 of haem binding suggest that these are involved in iron scavenging in association with transport into the cell via the iron $\mathrm{ABC}$ transport complex.

PA-4687, 5541 and 25957, in contrast to PA-21693, showed a degree of sequence diversity amongst the 20 clinical isolates studied; these included type IA, IB and II $P$. acnes. This diversity was generated by repeat sequences towards the midregion and carboxy-terminus. In addition, sequence comparison of these isolates identified frameshifts that disrupted the signal sequences in PA-4687, 5541 and 25957 in some type IB and type II isolates. In the M-like proteins PA-25957 and 5541 this shift was generated by variable numbers of $C$ residues in a $\mathrm{C}_{\mathrm{n}} \mathrm{TC}_{\mathrm{n}}$ motif just upstream of the putative signal peptide cleavage site. The sequence data indicate that there is the potential for both phase variation (i.e. expression or nonexpression of an individual protein) and antigenic variation (i.e. expression of different antigenic variants of the same protein) amongst different isolates. Initial immunoblot comparisons of expression of these proteins by selected type IA and IB isolates revealed multiple banding patterns. Although these may be attributed to protein degradation during processing or association with cell wall or membrane material, it is more likely that the observed molecular mass heterogeneity has been generated by multiple start sites and within-clone variation. For example, with respect to PA-4687 in isolates GN-3 and PA-1, the multiple bands in the higher molecular mass region are absent and only a single band of approximately $41 \mathrm{kDa}$ is detected. This is likely to have arisen from a second start site downstream of the frameshifted signal sequence. The comparison of the sequence data between isolates, particularly in the repeat regions of the proteins, is highly suggestive of insertions and deletions having arisen by slipped-strand mispairing as found in other pathogenic bacteria (van der Woude \& Baumler, 2004). Therefore the molecular mass heterogeneity could also have been generated by within-clone variation. We are currently carrying out indepth analyses of within- and between-isolate expression of these proteins.

The M-like antigens PA-25957 and PA-5541, based on both sequence similarities and adhesion assays that demonstrated specific dermatan sulphate-binding properties, are likely to be MSCRAMMs (microbial surface components recognizing adhesive matrix molecules). Although PA-4687 has some similarity with PA-21693 it is unlikely that it has a central role in iron uptake mechanisms. 


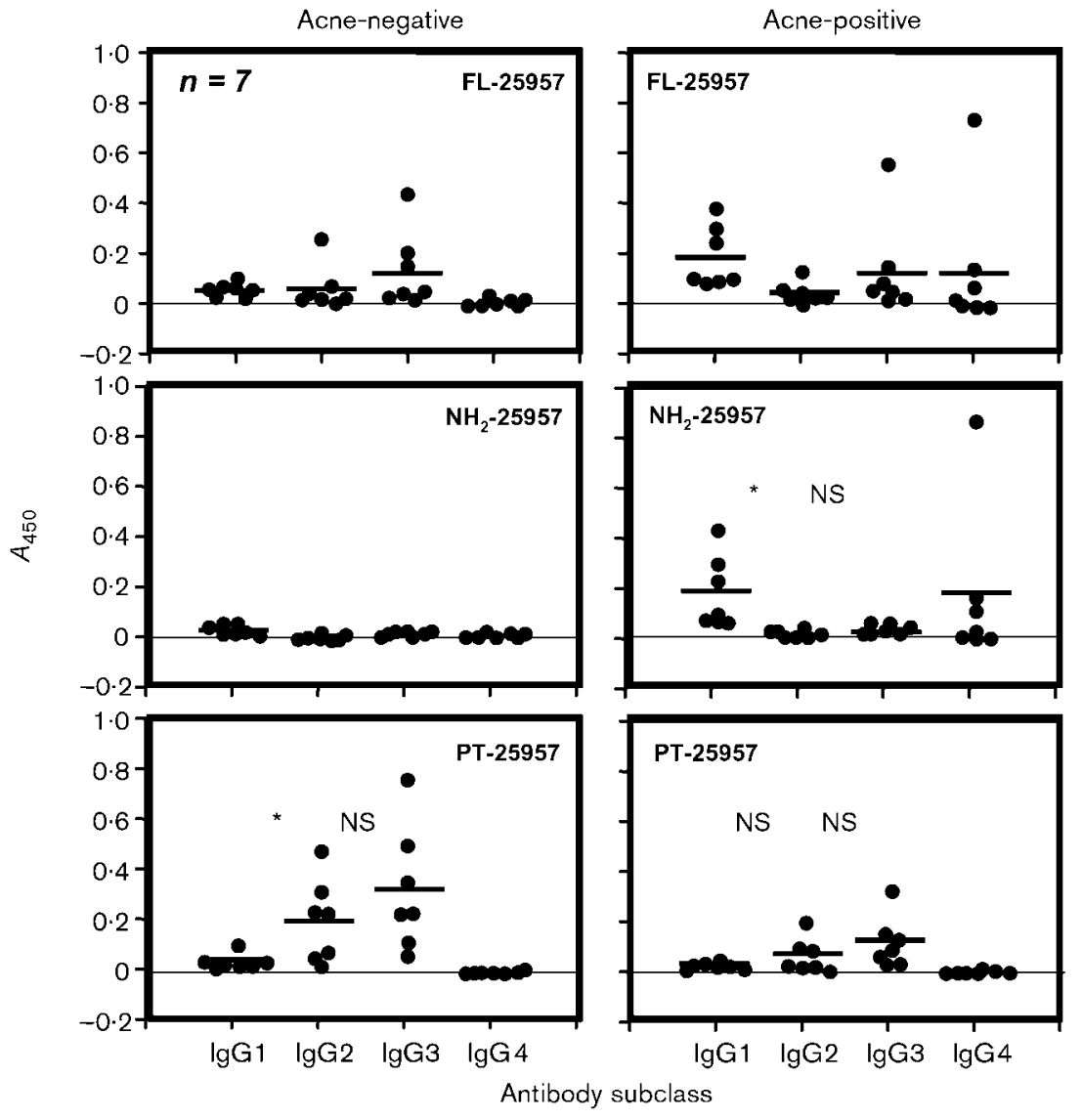

Fig. 9. ELISA results for acne-positive and negative donor subclass antibody response to PA-25957; full-length protein (FL) and the amino-terminal $\left(\mathrm{NH}_{2}\right)$ and carboxy-terminal (PT) fragments of r25957. Dots represent individual donor antibody results and horizontal bars indicate the mean antibody responses. Sera were tested at 1:50 dilution. Significant differences between groups $(P \leqslant 0.05)$, as determined by Student's $t$ test, are indicated by asterisks between the respective pairs; non-significant differences $(P>0.05)$ are indicated by NS between the respective pairs.
Epitope mapping studies of the M-like PA-25957 indicate that the region towards the amino-terminus of this polypeptide is recognized by antibody in serum from acne-positive individuals and contains a $\mathrm{CD}^{+}{ }^{+} \mathrm{T}$ cell epitope. The region of this antigen towards the carboxyterminus, in contrast, is recognized by antibody in serum from acne-negative donors. Of interest is the IgG1/T cell response to the amino-terminus of recombinant PA-25957 from individuals with a history of moderate to severe acne and the dissimilar IgG2/3 response to the carboxy-terminus of this molecule in individuals with a history of mild acne. A recent study indicated that patients with severe atopic dermatitis demonstrated a skewing of the antibody response to staphylococcal enterotoxin C1 (SEC1), with a selective deficiency in the production of anti-SEC1 IgG2 and enhanced levels of IgG1 and 4 against this antigen. A similar skewing of the SEC1-specific $\mathrm{T}$ cell response was observed in these patients, with selective production of IL-4 and IL-5, whereas PBMCs from patients with high levels of anti-SEC1 IgG2 failed to produce these cytokines (MrabetDahbi et al., 2005). It will be interesting to determine whether a similar phenomenon (i.e. a diminished IgG2/3 and elevated IgG1/4 response to PA-25957) is occurring in individuals with severe acne. This finding could also be important both in selecting the antigens for a therapeutic vaccine and also in selecting the important epitopes of that antigen that could drive the desired immune response. The possibility that a deregulated immune response to $P$. acnes antigens could be occurring in individuals with severe inflammatory acne remains to be investigated.

Recent data suggest a role for $P$. acnes in both innate and acquired immunity. $P$. acnes antigens are thought to activate Toll-like receptors, especially TLR2, that would result in the release of proinflammatory cytokines (Koreck et al., 2003). In addition, $P$. acnes-specific $\mathrm{CD}^{+}{ }^{+} \mathrm{T}$ cells have been generated from acne lesions. Resulting $\mathrm{T}$ cell lines could be induced to proliferate and release cytokines in response to $P$. acnes antigens (Mouser et al., 2003). Evidence now suggests that inflammation in acne is initiated by a $P$. acnes-specific $\mathrm{CD} 4{ }^{+} \mathrm{T}$ cell response (Farrar \& Ingham, 2004). Indeed, it has been postulated that immunogenic $P$. acnes proteins released into the follicle could be processed by Langerhan's cells, which could, in turn, present these antigens to $\mathrm{CD} 4^{+}$ $\mathrm{T}$ cells in local lymph nodes (Farrar \& Ingham, 2004). Migration of activated $\mathrm{T}$ cells back to the skin and the subsequent release of cytokines could result in inflammation. It is possible that the acute phase of inflammatory acne is driven by both the innate immune system, including Tolllike receptor TLR-2, and also by the adaptive immune system, driven by a Th-1 response to specific $P$. acnes antigens. 


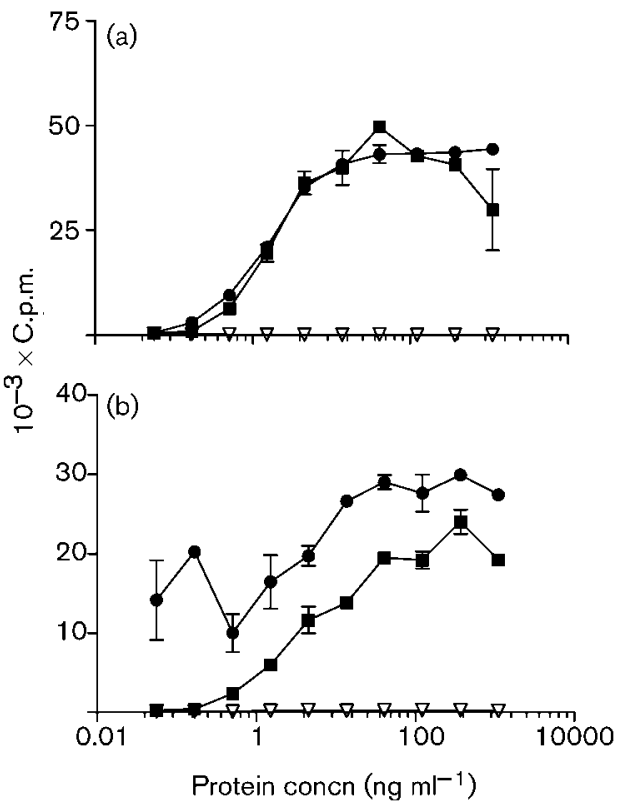

Fig. 10. $\mathrm{CD}^{+}{ }^{+} \mathrm{T}$ cell epitope mapping of PA-25957 and PA5541. $T$ cells from a $P$. acnes-specific $T$ cell line (line $A$ ) were incubated with the indicated concentrations of (a) r25957 protein ( $\boldsymbol{\square}$, full-length protein; $\boldsymbol{\bullet}$, amino-terminal region lacking the PT repeat region; $\nabla$, carboxy-terminal including the PT region) and (b) r5541 protein ( $\boldsymbol{\square}$, full-length protein; $\boldsymbol{O}$, aminoterminal region lacking the PT repeat region; $\nabla$, culture medium with no protein).

It is likely that the considerable potential for variation in the immunogenic surface components, as described herein, affects the degree of severity of acne and other conditions in which $P$. acnes is implicated, in different individuals.

\section{ACKNOWLEDGEMENTS}

We thank Drs M. Coyle, Department of Microbiology and Laboratory Medicine (emeritus), and Director, Harborview Medical Center Microbiology (retired), Seattle, WA 98104, USA (PA isolates); J. J. Leyden, Department of Dermatology, University of Pennsylvania, Philadelphia, PA 19104, USA (Z isolates); and R. Romiti, Department of Dermatology, Ruhr-University, Bochum, Germany (GN and GP isolates) for providing P. acnes isolates. We thank Drs Robert Jones and Jennifer Mitcham for their efforts on organization and bioinformatics for the Corixa Corporation P. acnes genome-sequencing project. This work was funded by Corixa Corporation, a wholly owned subsidiary of GlaxoSmithKline Biologicals. S. P.'s laboratory has funding from the Northern Ireland Health and Personal Social Services Research and Development Office.

\section{REFERENCES}

Bendtsen, J. D., Nielsen, H., von Heijne, G. \& Brunak, S. (2004). Improved prediction of signal peptides: SignalP 3.0. J Mol Biol 340, 783-795.

Bojar, R. A. \& Holland, K. T. (2004). Acne and Propionibacterium acnes. Clin Dermatol 22, 375-379.
Braga, E. G., Ananias, R. Z., Mussalem, J. S., Squaiella, C. C., Longhini, A. L., Mariano, M., Travassos, L. R. \& Longo-Maugeri, I. M. (2003). Treatment with Propionibacterium acnes modulates the late phase reaction of immediate hypersensitivity in mice. Immunol Lett 88, 163-169.

Brook, I. (2002). Endocarditis due to anaerobic bacteria. Cardiology 98, 1-5.

Bruggemann, H., Henne, A., Hoster, F., Liesegang, H., Wiezer, A., Strittmatter, A., Hujer, S., Durre, P. \& Gottschalk, G. (2004). The complete genome sequence of Propionibacterium acnes, a commensal of human skin. Science 305, 671-673.

Clamp, M., Cuff, J., Searle, S. M. \& Barton, G. J. (2004). The Jalview Java alignment editor. Bioinformatics 20, 426-427.

Cove, J. H., Holland, K. T. \& Cunliffe, W. J. (1983). Effects of oxygen concentration on biomass production, maximum specific growth rate and extracellular enzyme production by three species of cutaneous propionibacteria grown in continuous culture. $J$ Gen Microbiol 129, 3327-3334.

Davies, M. (1982). Bacterial cells as anti-tumour agents in man. Rev Environ Health 4, 31-56.

Eady, E. A., Cove, J. H., Holland, K. T. \& Cunliffe, W. J. (1989). Erythromycin resistant propionibacteria in antibiotic treated acne patients: association with therapeutic failure. Br J Dermatol 121, 51-57.

Eady, E. A., Gloor, M. \& Leyden, J. J. (2003). Propionibacterium acnes resistance: a worldwide problem. Dermatology 206, 54-56.

Farrar, M. D. \& Ingham, E. (2004). Acne: inflammation. Clin Dermatol 22, 380-384.

Frick, I. M., Schmidtchen, A. \& Sjobring, U. (2003). Interactions between M proteins of Streptococcus pyogenes and glycosaminoglycans promote bacterial adhesion to host cells. Eur J Biochem 270, 2303-2311.

Gao, T. W., Li, C. Y., Zhao, X. D. \& Liu, Y. F. (2002). Fatal bacteria granuloma after trauma: a new entity. Br J Dermatol 147, 985-993.

Gribbon, E. M., Cunliffe, W. J. \& Holland, K. T. (1993). Interaction of Propionibacterium acnes with skin lipids in vitro. J Gen Microbiol 139, 1745-1751.

Holland, K. T., Holland, D. B., Cunliffe, W. J. \& Cutcliffe, A. G. (1993). Detection of Propionibacterium acnes polypeptides which have stimulated an immune response in acne patients but not in normal individuals. Exp Dermatol 2, 12-16.

Ingham, E. (1999). The immunology of Propionibacterium acnes and acne. Curr Opin Infect Dis 12, 191-197.

Jappe, U., Ingham, E., Henwood, J. \& Holland, K. T. (2002). Propionibacterium acnes and inflammation in acne; $P$. acnes has T-cell mitogenic activity. Br J Dermatol 146, 202-209.

Johnson, J. L. \& Cummins, C. S. (1972). Cell wall composition and deoxyribonucleic acid similarities among anaerobic coryneforms, classical propionibacteria, and strains of Arachnia propionica. J Bacteriol 109, 1047-1066.

Jousimies-Somer, H. R., Summanen, P., Citron, D. M., Baron, E. J., Wexler, H. M. \& Finegold, S. M. (2002). Wadsworth-KTL Anaerobic Bacteriology Manual, 6th edn. Belmont: Star Publishing Co.

Kim, J., Ochoa, M.-T., Krutzik, S. R. \& 10 other authors (2002). Activation of Toll-like receptor 2 in acne triggers inflammatory cytokine responses. J Immunol 169, 1535-1541.

Kirchhoff, T., Merkesdal, S., Rosenthal, H. \& 7 other authors (2003). Diagnostic management of patients with SAPHO syndrome: use of MR imaging to guide bone biopsy at CT for microbiological and histological work-up. Eur Radiol 13, 2304-2308.

Koreck, A., Pivarcsi, A., Dobozy, A. \& Kemeny, L. (2003). The role of innate immunity in the pathogenesis of acne. Dermatology 206, 96-105. 
Lee, S. G., Pancholi, V. \& Fischetti, V. A. (2002). Characterization of a unique glycosylated anchor endopeptidase that cleaves the LPXTG sequence motif of cell surface proteins of Gram-positive bacteria. J Biol Chem 277, 46912-46922.

Leyden, J. J., McGinley, K. J. \& Vowels, B. (1998). Propionibacterium acnes colonization in acne and nonacne. Dermatology 196, 55-58.

Lodes, M. J., Cong, Y., Elson, C. O., Mohamath, R., Landers, C. J., Targan, S. R., Fort, M. \& Hershberg, R. M. (2004a). Bacterial flagellin is a dominant antigen in Crohn's disease. J Clin Invest 113, 1296-1306.

Lodes, M. J., Dillon, D. C., Houghton, R. L. \& Skeiky, Y. A. W. (2004b). Expression cloning. In Molecular Diagnosis of Infectious Diseases, 2nd edn, pp. 91-106. Edited by J. Decker \& U. Reisch. New Jersey: Humana Press.

Matsui, K., Yoshimoto, T., Tsutsui, H. \& 7 other authors (1997). Propionibacterium acnes treatment diminishes $\mathrm{CD} 4{ }^{+} \mathrm{NK} 1.1^{+} \mathrm{T}$ cells but induces type I T-cells in the liver by induction of IL-12 and IL-18 production from Kupffer cells. J Immunol 159, 97-106.

Moller, D. R. \& Chen, E. S. (2002). What causes sarcoidosis? Curr Opin Pulm Med 8, 429-434.

Mouser, P. E., Baker, B. S., Seaton, E. D. \& Chu, A. C. (2003). Propionibacterium acnes-reactive $\mathrm{T}$ helper-1 cells in the skin of patients with acne vulgaris. J Invest Dermatol 121, 1226-1228.

Mrabet-Dahbi, S., Breuer, K., Klotz, M., Herz, U., Heeg, K., Werfel, T. \& Renz, H. (2005). Deficiency in immunoglobulin G2 antibodies against staphylococcal enterotoxin $\mathrm{C} 1$ defines a subgroup of patients with atopic dermatitis. Clin Exp Allergy 35, 274-281.

Nagy, I., Pivarcsi, A., Koreck, A., Szell, M., Urban, E. \& Kemeny, L. (2005). Distinct strains of Propionibacterium acnes induce selective human beta-defensin-2 and interleukin-8 expression in human keratinocytes through toll-like receptors. J Invest Dermatol 124, 931-938

Nagy, I., Pivarcsi, A., Kis, S. \& 7 other authors (2006). Propionibacterium acnes and lipopolysaccharide induce the expression of antimicrobial peptides and proinflammatory cytokines/chemokines in human sebocytes Microbes Infect 8, 2195-2205.

Pallen, M. J., Lam, A. C., Antonio, M. \& Dunbar, K. (2001). An embarrassment of sortases - a richness of substrates? Trends Microbiol 9, 97-102.

Proft, T., Hilbert, H., Layh-Schmitt, G. \& Herrmann, R. (1995). The proline-rich $\mathrm{P} 65$ protein of Mycoplasma pneumoniae is a component of the Triton X-100-insoluble fraction and exhibits size polymorphism in the strains M129 and FH. J Bacteriol 177, 3370-3378.

Qian, Y., Lee, J. H. \& Holmes, R. K. (2002). Identification of a DtxR-regulated operon that is essential for siderophore-dependent iron uptake in Corynebacterium diphtheriae. J Bacteriol 184, 4846-4856.

Rodriguez, G. M., Voskuil, M. I., Gold, B., Schoolnik, G. K. \& Smith, I. (2002). ideR, an essential gene in Mycobacterium tuberculosis: role of IdeR in iron-dependent gene expression, iron metabolism, and oxidative stress response. Infect Immun 70, 3371-3381.

Schmitt, M. P. \& Drazek, E. S. (2001). Construction and consequences of directed mutations affecting the hemin receptor in pathogenic Corynebacterium species. J Bacteriol 183, 1476-1481.

Schneewind, O., Fowler, A. \& Faull, K. F. (1995). Structure of the cell wall anchor of surface proteins in Staphylococcus aureus. Science $\mathbf{2 6 8}$, 103-106.

Smith, K. M., Brewer, J. M., Rush, C. M., Riley, J. \& Garside, P. (2004). In vivo generated Th1 cells can migrate to $B$ cell follicles to support B cell responses. J Immunol 173, 1640-1646.

Targan, S. R., Landers, C. J., Yang, H., Lodes, M. J., Cong, Y., Papadakis, K. A., Vasiliauskas, E., Elson, C. O. \& Hershberg, R. M. (2005). Antibodies to CBir1 flagellin define a unique response that is associated independently with complicated Crohn's disease. Gastroenterology 128, 2020-2028.

Thompson, J. D., Higgins, D. G. \& Gibson, T. J. (1994). CLUSTAL W: improving the sensitivity of progressive multiple sequence alignment through sequence weighting, position-specific gap penalties and weight matrix choice. Nucleic Acids Res 22, 4673-4680.

Tunney, M. M., Patrick, S., Gorman, S. P., Nixon, J. R., Anderson, N., Davis, R. I., Hanna, D. \& Ramage, G. (1998). Improved detection of prosthetic hip infection: a currently underestimated problem. J Bone Joint Surg 80-B, 568-572.

Tunney, M. M., Patrick, S., Curran, M. D., Ramage, G., Hanna, D., Nixon, J. R., Gorman, S. P., Davis, R. I. \& Anderson, N. (1999). Detection of prosthetic hip infection at revision arthroplasty by immunofluorescence microscopy and PCR amplification of the bacterial 16S rRNA gene. J Clin Microbiol 37, 3281-3290.

Valanne, S., McDowell, A., Ramage, G. \& 10 other authors (2005). CAMP factor homologues in Propionibacterium acnes: a new protein family differentially expressed by types I and II. Microbiology 151, 1369-1379.

van der Woude, M. W. \& Baumler, A. J. (2004). Phase and antigenic variation in bacteria. Clin Microbiol Rev 17, 581-611.

Wong, T., Ormonde, S., Gamble, G. \& McGhee, C. N. (2003). Severe infective keratitis leading to hospital admission in New Zealand. $\mathrm{Br}$ J Ophthalmol 87, 1103-1108.

Zedtwitz-Liebenstein, K., Gabriel, H. \& Graninger, W. (2003). Pacemaker endocarditis due to Propionibacterium acnes. Infection 31, 184-185. 